Journal of Archaeological Method and Theory, 2019, 26 (1), pp. 276-312

DOI : https://doi.org/10.1007/s10816-018-9372-4

\title{
Birch Bark Tar Production: Experimental and Biomolecular Approaches to the Study of a Common and Widely Used Prehistoric Adhesive
}

Maxime Rageot ${ }^{1,2,3}$, Isabelle Théry-Parisot ${ }^{1}$, Sylvie Beyries ${ }^{1}$, Cédric Lepère ${ }^{1,4}$, Alain Carré ${ }^{1}$, Arnaud Mazuy $^{1}$, Jean-Jacques Filippi ${ }^{2}$, Xavier Fernandez ${ }^{2}$, Didier Binder ${ }^{1}$, Martine Regert ${ }^{1}$

1 - Université Côte d'Azur, CNRS, CEPAM, Nice, France

2 - Université Côte d'Azur, CNRS, ICN, Nice, France

3 - Present address: Department of Pre- and Protohistory, University of Tübingen, Burgsteige 11, 72070 Tübingen, Germany

4 - Eveha- Etudes et Valorisation Archéologiques, Lyon, France

\begin{abstract}
Birch bark tar, the oldest adhesive known in Europe, was widely used during Prehistory. This material, produced by the dry distillation of birch bark, has been identified in various spheres of activities and provides valuable information on the know-how and technical and territorial systems of past societies. This biomaterial can also provide evidence on socio-economic networks and mobility. However, very little is known about the production systems of birch bark tar during Prehistory, including the Neolithic period. The lack of findings in the archaeological record necessitates the development of an approach that combines experimental archaeology and biomolecular chemistry. We present here (1) the results of experiments in which different birch bark tar production systems were tested and (2) the molecular signatures of the birch bark tars produced according to different processes based on the use of ceramic vessels. The key role of bark quality is highlighted for the first time. This study also details direct archaeological inference of the experimental results obtained: a total of 23 samples from the site of NiceGiribaldi (France, second part of the fifth century BCE) was investigated. Different categories of birch bark tars were identified during Neolithic in the south of France, providing evidence for the existence of complex manufacturing systems and procurement networks.
\end{abstract}

\section{Keywords}

Birch bark tar; System of production; Experimental archaeology; Biomolecular archaeology; Neolithic; Chassey culture 


\section{Introduction}

The study of plant sub-products such as resins and tars can also contribute to a better understanding of plant exploitation. Such materials may be preserved in the archaeo-logical record as amorphous organic residues, either associated with a variety of objects or utensils (ceramic vessels, lithic and bone tools, etc.) or as free lumps within the sedimentary matrix. The study of such remains is less common than that of other botanical evidence because of their low degree of preservation and the need of chemical analyses for their identification. Due to their valuable properties, plant exudates and tars have nevertheless been largely used over time as adhesives, waterproofing agents, varnish, medicines. Such materials are now routinely characterised using a range of analytical techniques combining infrared spectrometry, mass spectrometry and chro-matographic methods (Hayek et al. 1990; Regert and Rolando 2002; Colombini and Modugno 2009; Daher et al. 2010; Ribechini et al. 2011; Bruni and Guglielmi 2014). Some resins (pine, pistachio tree, frankincense and copal) and tars (conifer, birch bark) have been identified in archaeological samples such as art objects or residues (Evershed et al. 1985; Regert et al. 1998, 2003, 2008; Stern et al. 2008; Colombini et al. 2009; Rageot et al. 2016). However, very little is known on their systems of production, and key questions regarding the choice and harvesting of the raw materials, the manufactur-ing processes, the organisation of the production and the level of craftsmanship, especially for prehistoric times, still remain unanswered. Topics such as the location and the socio-economic organisation of the production system (domestic or specialised activity) have never been explored in practical settings, and the same holds true about the influence of season on the harvesting and the quality of the raw material required to produce tar.

In the study reported here, we focussed on birch bark tar, which is the most commonly used material during European Prehistory (Figure 1) as adhesive for hafting tools or mending pottery vessels, as well as waterproofing agent (Binder et al. 1990; Bonfield et al. 1997; Regert et al. 1998; Aveling and Heron 1998; Grünberg 2002; Urem-Kotsou et al. 2002; Mazza et al. 2006; Mitkidou et al. 2008; Mirabaud et al. 2015; Regert and Mirabaud 2014) or as a decorative element (Bosquet et al. 2001, Sauteret al. 2002; Rageot et al. 2016). This material was also probably employed for medicinal purposes as evidenced by the discov-ery of birch bark tar "chewing gums" (Evans and Heron 1993; Aveling and Heron 1999) and perhaps for its odoriferous properties in funerary contexts (Lucquin et al. 2007).

In order to understand the modalities of acquisition and transformation of birch bark and to discriminate the various systems of production, we combined the complementary approaches of experimental archaeology and analytical chemistry. Our methodology included (i) the harvesting of birch bark in a diversity of physiological and phenological states from different contexts in southern France, (ii) the production of birch bark tar in an experimental setting using several different methods and (iii) the analysis of the experimental tars thus produced using gas chromatography (GC) and combined GC-mass spectrometry (GC-MS). The data obtained were then used to interpret data acquired on archaeological samples discovered at the Neolithic (Southern Chassey culture) site of Nice-Giribaldi (Nice, France) where an important amount of birch bark tar was discov-ered (Binder et al. 1990; Regert et al. 2000). 


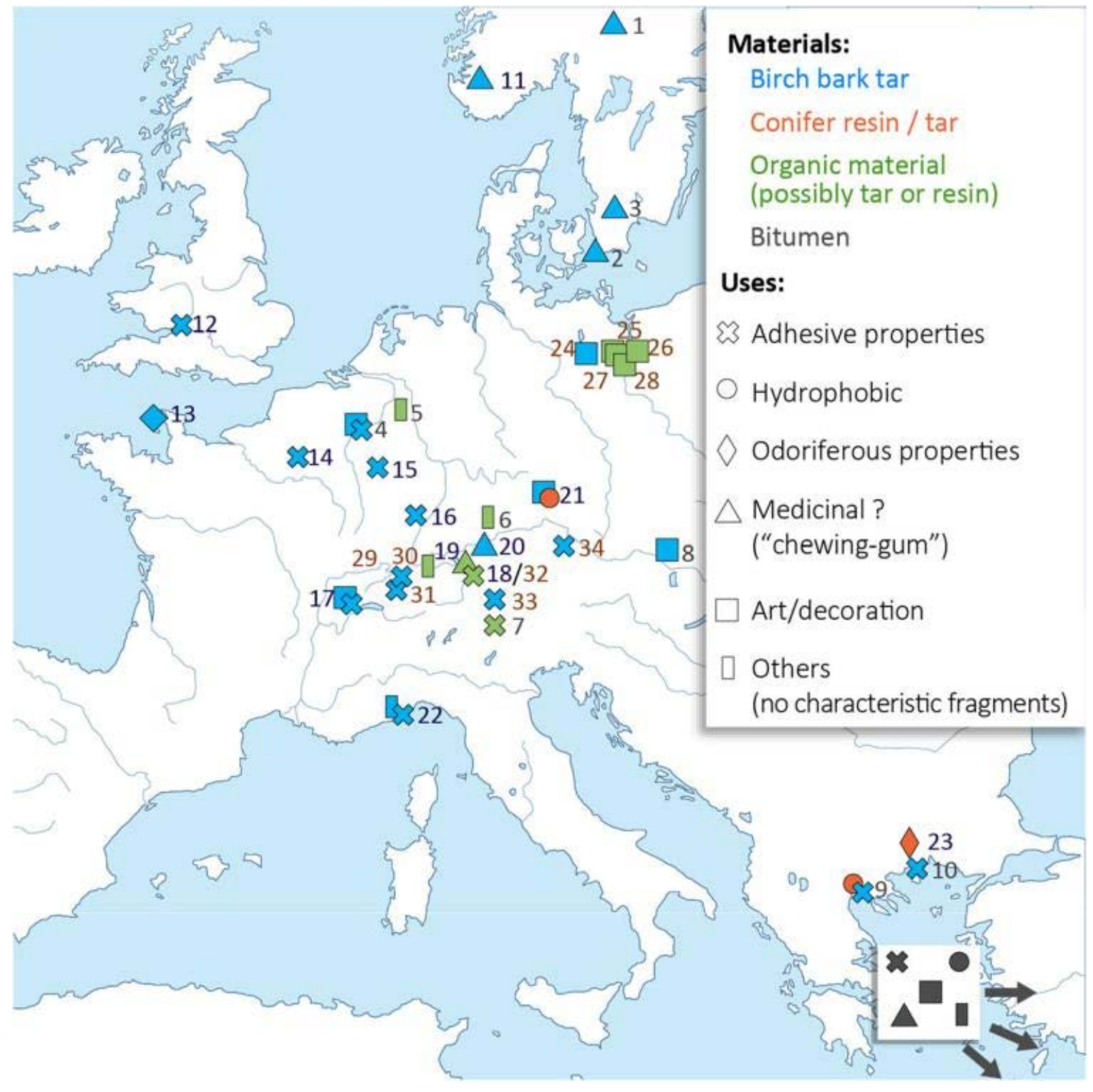

Figure 1 - Plant tars and resins exploitation in Europe during recent Prehistory (6000-2500 BC). Information is based solely on published works which involved chemical investigation. 6th millennium BC: 1: Ringsjöholm; 2: Segebro; 3: Bokeberg; 4: Podrî l’Cortri; 5: Erklelenz-Kückhoven; 6: Henauhof Nord II; 7: Gaban rockshelter; 8: Brunn am Gebirge; 9: Makriyalos; 10: Paliambela. Second part of 5th millennium and first part of 4th millennium BC: 11: Ovre Storvatnet; 12: Sweet Track; 13: La Hougue Bie; 14: Beaurieux; 15: Waldbillig Karelslé; 16: Rosheim; 17: Clairvaux VII and XIV; 18: Zürich Seefeld; 19: Burgäschi-Ost,Seeberg; 20 : Hornstaad Hornle I; 21: Ergolding Fischergasse; 22: Nice-Giribaldi; 23: Dikili Tash. Transition 4th and 3rd millennium BC: 24: zulawka mala; 25: Bakowo Site 3; 26: Jezuicka Struga; 27: Opatowice Site 42; 28: Papros Site 6B; 29: Chalain 2, 3 and 4; 30: Portalban; 31: Montilier; 32: Zürich Seefeld; 33: Ötzi; 34: Mondsee. 


\section{The Different Systems of Tar Production}

During prehistoric times birch bark tar was ubiquitous in Europe while bitumen was exploited in the Near East, although adhesive materials were probably more diversified (Rageot 2015). The lack of findings related to tar production during Prehistory necessitates the development of an experimental approach in order to gain an understanding of the conditions of birch bark tar manufacture and the level of « savoir-faire » involved.

The literature published in the field of experimental archaeology on the produc-tion systems known to have been used to make wood or bark tars has mainly focused on post-prehistoric periods, including traditional practices in more recent times (Rajewsky 1970; Czarnowski and Neubauer 1990; Czarnowski et al. 1990; Kurzweil and Todtenhaupt 1991; Szafranski 1997; Egenberg et al. 2003; Kurt et al. 2008; Kurt and Isik 2012; Burri 2012) despite recent published findings having provided new data related to Palaeolithic aceramic societies (Osipowicz 2005; Palmer 2007; Groom et al. 2015; Kozowyk et al. 2017; Schenck and Groom 2018). Published studies mainly report two processes corresponding to autothermic and allothermic systems as defined by Kurzweil and Todtenhaupt (1991) at the beginning of the 1990s. Figure 2 illustrates the different known methods of tar production that are discussed in the following text.

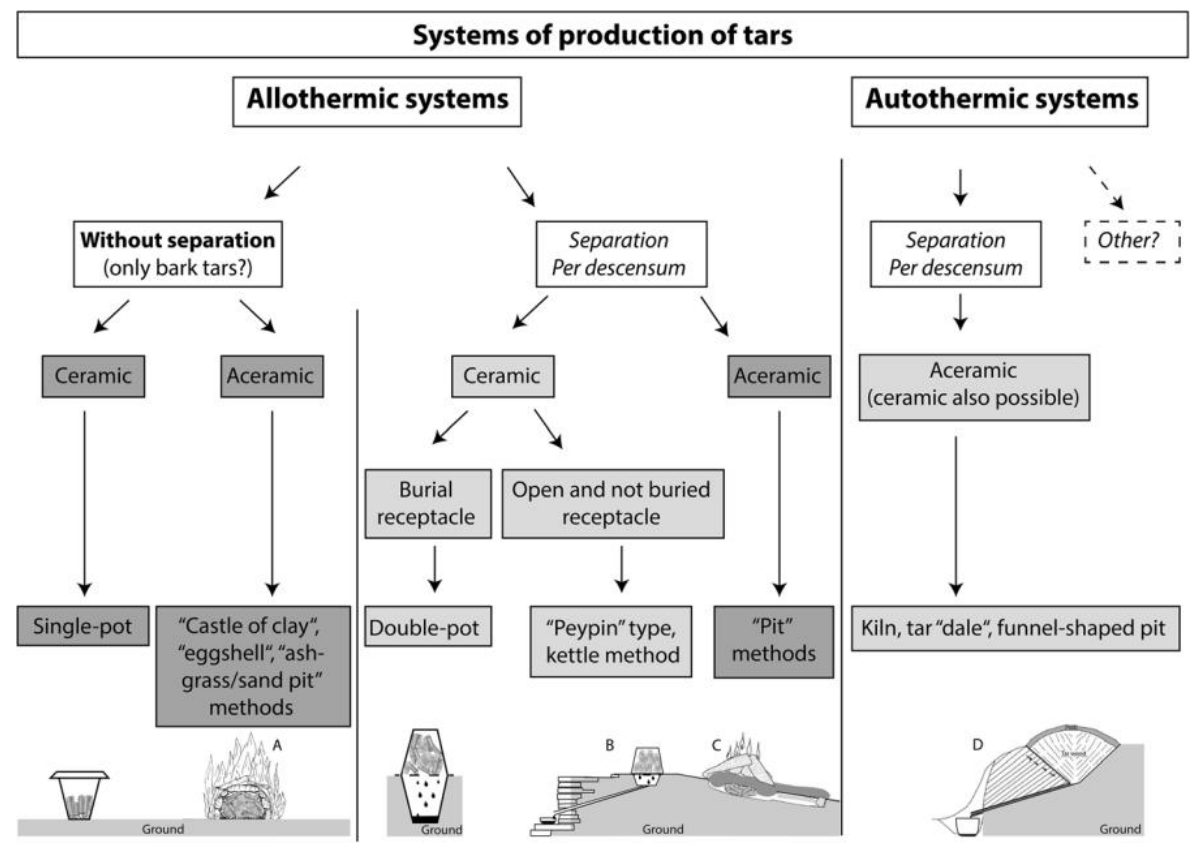

Figure 2 - Different systems of production of tars. Systems already identified in archaeological contexts (Historic periods) are given in light grey and systems that have been experimented in previous studies are shown in dark grey. A: "Castle of clay method", adapted from Osipowicz 2005; B: "Peypin method", adapted from Burri 2012; C: "Slope pit method”, adapted from Groom et al. 2015; D: "tar dale method", adapted from Hjulström et al. 2006 


\section{Autothermic and Allothermic Systems}

The autothermic system relies on the direct transfer of heat to the raw material without heat conductors (processes involving, for example, a kiln or funnel-shaped pit; see Figure 2). Useful for wood tar production, this process has been largely described, especially for conifer tar (Rajewsky 1970; Kurzweil and Todtenhaupt 1991; Egenberg et al. 2003; Kurt et al. 2008; Kurt and Isik 2012; Burri 2012). However, this system does not seem adapted for a significant production of tars made from bark, as this latter material is easily flammable. Cassen and François (2009) noted that birch bark is flammable enough to light a fire in all types of weather, even in rainy conditions. The production of birch bark tar also requires dry distillation that excludes oxygen (Koller and Baumer 2001).

The essence of allothermic systems is the induction of the reaction by indirect heat transfer to the raw material. Ceramic or metal vessels, but also clay, sand, ash, turf and ovens, are generally used (Rajewski 1970; Czarnowski and Neubauer 1990; Czarnowski et al. 1990; Kurzweil and Todtenhaupt 1991; Szafranski 1997; Osipowicz 2005; Kozowyk et al. 2017; Schenck and Groom 2018). Among allothermic systems, the so-called per descensum processes, in particular, the double-pot methods are the most described and tested (Kurzweil and Todtenhaupt 1991; Szafranski 1997; Voß 1997; Julin 2008). The term per descensum refers to a process in which the tar formed during the heating treatment is directly separated from bark sub-products by gravity. In the double-pot method, birch bark is placed in an upper container (often with a perforated base) that is exposed to fire. The tar produced flows into a second receptacle hermetically sealed to the first one and buried underground (Figure 2). Within the allothermic methods, scholars have also described another procedure without the separation of tar seen in per descensum processes (Czarnowski et al. 1990; Neubauer-Saurer 1997; Osipowicz 2005): in this procedure, known as single-pot method, the tar formed during the heating treatment remains in the vessel and mixes with the fibrous residues of the bark to form a different type of adhesive material (Figure 2).

\section{Archaeological Evidence and Historical Sources}

Although the use of plant tars is largely documented in Prehistory, archaeological evidence on the manufacturing methods involved in their production is almost entirely absent, in particular for bark tar, albeit it being one of the most common adhesive produced during Prehistory in Europe. A single example is reported at the Mesolithic site in Ullafelsen in Austria where carbonised pieces of wood showing traces of tar exudation were discovered in a pit (Pawlik 2011). This finding may suggest a wood tar production using an autothermic system. Such thermic systems, using conifer woods, are indeed referenced for more recent periods by historical and ethnographical sources (Kurzweil and Todtenhaupt 1991; Zakoscielna and Gurba 1997; Egenberg et al. 2003; Hjulström et al. 2006; Burri 2012; Orengo et al. 2013).

For allothermic process, the most ancient evidence dates back to the final Bronze Age in Northern Italy and corresponds to a double-pot system (Dal Ri and Tecchiati 2003). However, the amorphous residues found in the perforated holes of the ceramic vessels were subjected to a chemical investigation. This system is more frequently found in Western Europe during Roman times (Balsan 1951; Jauch 1994; Connan et al. 2002; Trintignac 2003) and in Central Europe during Middle Ages (Schoknecht and Schwartze 1964; Kurzweil and Todtenhaupt 1991; Voß 1997). In all of these cases, conifer tar was identified when the organic residues were investigated chemically. Other per descensum systems without a buried receptacle for tar, such as the "Peypin" type (Burri, 2012) and the Kettle method (Kurzweil and Todtenhaupt, 1991), or by using ovens (Todtenhaupt and Kurzweil 1997) are also described for Late Antiquity sites (Figure 2).

Tar manufacture is often closely related with other practices, especially charcoal production, as described in some regions of Norway, Russia and France (Lepers 2007). It may also be linked with early blacksmithing activities as recently described for Roman period in the Pyrenees Mountains (Orengo et al. 2013). In that case, the production of tar was part of a more comprehensive system characterised by an efficient and sustainable management of plant settings. Indeed, a balance has to be maintained between the exploitation and the regeneration of the resources to avoid deforestation and to maintain the activity. This explains that tar production is sometimes seasonally organised, but also depends on the accessibility of production area and the availability of natural resources (Orengo et al. 2013; Trintignac 2003). 


\section{Experimental Production of Birch Bark Tar: State of the Art}

Previous works have shown the efficiency of allothermic systems to make birch bark tar (Rajewski, 1970; Czarnowski and Neubauer 1990; Czarnowski et al. 1990; Kurzweil and Todtenhaupt 1991; Szafranski 1997; Osipowicz 2005; Palmer 2007; Kozowyk et al. 2017; Schenck and Groom 2018). Experimental studies also presented by Kurzweil and Todtenhaupt (1991) provided valuable indications for double-vessel systems, especially on installation of the hermetic system, the temperature parameters (heating in a fireplace until $700{ }^{\circ} \mathrm{C}$ for $3 \mathrm{~h}$ ), the physical aspects of the system and the yield of tar (around $10 \%)$. However, some of these experiments also described the production of complex tars through the mixing of birch bark and pine wood, which thus prevents the correct understanding of pure birch bark tar production. The single-pot method has also been successfully experimented with and the manner by which to produce birch bark tar precisely described, based on 16 experiments (Czarnowski et al. 1990; Neubauer-Saurer 1997). Information reported by these authors included temper-ature parameters (maximum of around $400{ }^{\circ} \mathrm{C}$ inside the pot, for20-40 min), but also the benefit of setting up a layout of birch bark rolls in the vessel. Theoretically, both allothermic systems could operate in their aceramic versions; for example, in the case of the single-pot method, the eggshell or "castle of clay" versions were successfully used in place of the ceramic vessel (experimental production of Tomas Pietsch in Biskupin in 2012; Osipowicz 2005). Pit systems are also able to replace the double-pot or other ceramicbased per descensum process (Groom et al. 2015; Kozowyk et al. 2017; Schenck and Groom 2018).

Such experimental studies have revealed a wide range of possibilities to produce birch bark tar. However, some of them are not standardised, and the reproducibility of the results is still to be established. Moreover, some crucial steps in the operating process were not tested. In such studies, there is usually very little information provided about the choice of the raw material and its influence on both the quality and yield of the tars obtained. Indeed, the bark itself has never been discussed in terms of its quality, the harvesting methods, the tree selection and the best harvest season (Théry-Parisot et al. accepted). Furthermore, available data are not always sufficient to compare the efficiency of the different methods investigated due to the variability of the tested operating processes and a lack of precision regarding temperature parameters. Finally, these previous experimental works were never combined with chemical analysis, except for tars obtained from conifer trees, including cedar and pine (Reunanen et al. 1996; Connan et al. 2002; Engenberg et al. 2002 and 2003; Hjulström et al. 2006; Kurt et al. 2008; Kurt and Isik 2012). 


\section{Materials and Methods}

In order to assess the importance of several parameters in production systems for birch bark tar, such as the quality of raw bark, the heating systems and temperature control, we have assessed different stages of the chaine opératoire of birch bark tar production.

Experiments were conducted using two different processes: one based on the per descensum procedure (named here the double-pot and first exudation method) and a second one that does not separate the tar issued from bark (the single-pot process). Tars produced using both processes were chemically analysed to establish biomolecular criteria allowing the correct discrimination of the different systems of production.

\section{Birch Bark Harvesting}

Experiments were carried out with barks of Betula pendula, a species that grows naturally in forests of the northwestern Mediterranean reliefs (Rameau et al. 1993 and 2008).

Several campaigns of bark harvesting were conducted: two in the Mercantour Park (Alpes Martitimes, France) at $1300 \mathrm{~m}$ a.s.l. and one in Alta Rocca (Corse-du-Sud, France) at $800 \mathrm{~m}$ a.s.l., during springtime (May and April 2012 and 2013). During this period, sap flows upward and the bark can be easily detached from the trees. The bark is composed of two layers, the suber (outer layer) and the liber (inner layer). It was sampled with care to prevent the death of the tree if the cambiale zone were to be altered by cutting too deeply.

One factor that potentially determines the characteristics of the products is the phenological state of the plant material prior to heating. Thus, we used three different grades to classify the collected barks according to their apparent quality, as well as the tree from which the barks were taken (Figure 3):

1 - AA-grade: supple and smooth barks; colour of internal surface is yellow to pink and the external surface is almost completely white. These barks were mostly harvested from young birch trees (yellow-brown-coloured trunk). They could also be obtained from trees that have fallen down or from relatively mature trees (after removing wood residues and most of external warts).

2 - A-grade: barks presenting a high proportion of internal warts that naturally occur for some Betula pendula. Such barks are less supple. Colour of the bark is the same as that of the "smooth-bark". These barks were mostly harvested from juvenile trees (green-coloured trunk) but also from a mature one.

3 - B-grade: barks affected by natural microbial decay (more rigid and with a dark colour). They came from dead trees on the ground. 


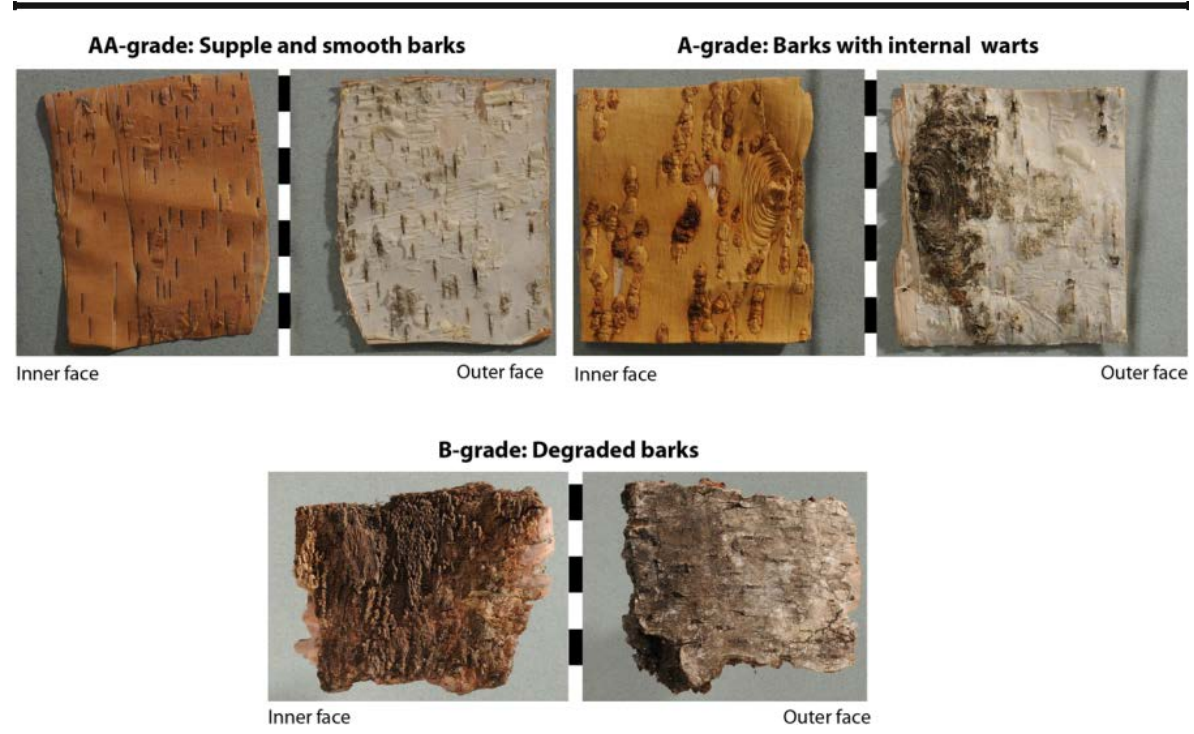

Figure 3 - The different qualities of the harvested bark graded according to the phenological state of the plant material.

The easiest bark to harvest is that from a dead tree; such bark can be removed by hand. The difficulty in removing bark from standing wood (using a knife) may vary depending on the age of the tree and the physical charac-teristics of the bark. For example, it is easier to harvest supple and smooth bark from young trees than to collect rigid bark presenting many warts on a mature tree. It should be noted that barks from juvenile trees were the most difficult to obtain. The harvesting period could also have an important role since it is easier to detach barks from the trunk at the end of May than in the beginning of April.

\section{Birch Bark Tar Manufacture}

A series of experiments was carried out to test different systems and parameters. A stepwise procedure was adopted. Preliminary laboratory experiments were conducted first to roughly determine the most suitable temperature programmes and types of bark to be used for open-air experiments. These lab-scale experiments allowed an easy and precise control of the temperatures and an evaluation of the different bark layout in the pots. Once these data were obtained, a final set of experiments was performed in the field where the conditions are more difficult to control but are more relevant to a prehistoric scenario.

In total, 44 experiments were performed: 2 experiments in test tubes, 33 using single-pot processes (20 in laboratory muffle furnace and 13 using an outdoor fireplace) and nine using double-pot processes (all performed in outdoor fireplaces). Anaerobic conditions were also tested for both single-pot and doublepot processes for which vessels were covered and hermetically sealed with clay (Figure 4). Temperature sensors were used for each experiment. Three parameters were taken into account: (1) the quality and freshness of the bark; (2) the arrangement of the bark within the pot; (3) the temperature conditions. The quality of the tar obtained was roughly evaluated (viscosity, adhesive quality) at the end of the experiments and its yield measured. Tars were chemically characterised by GC and GC-MS. 

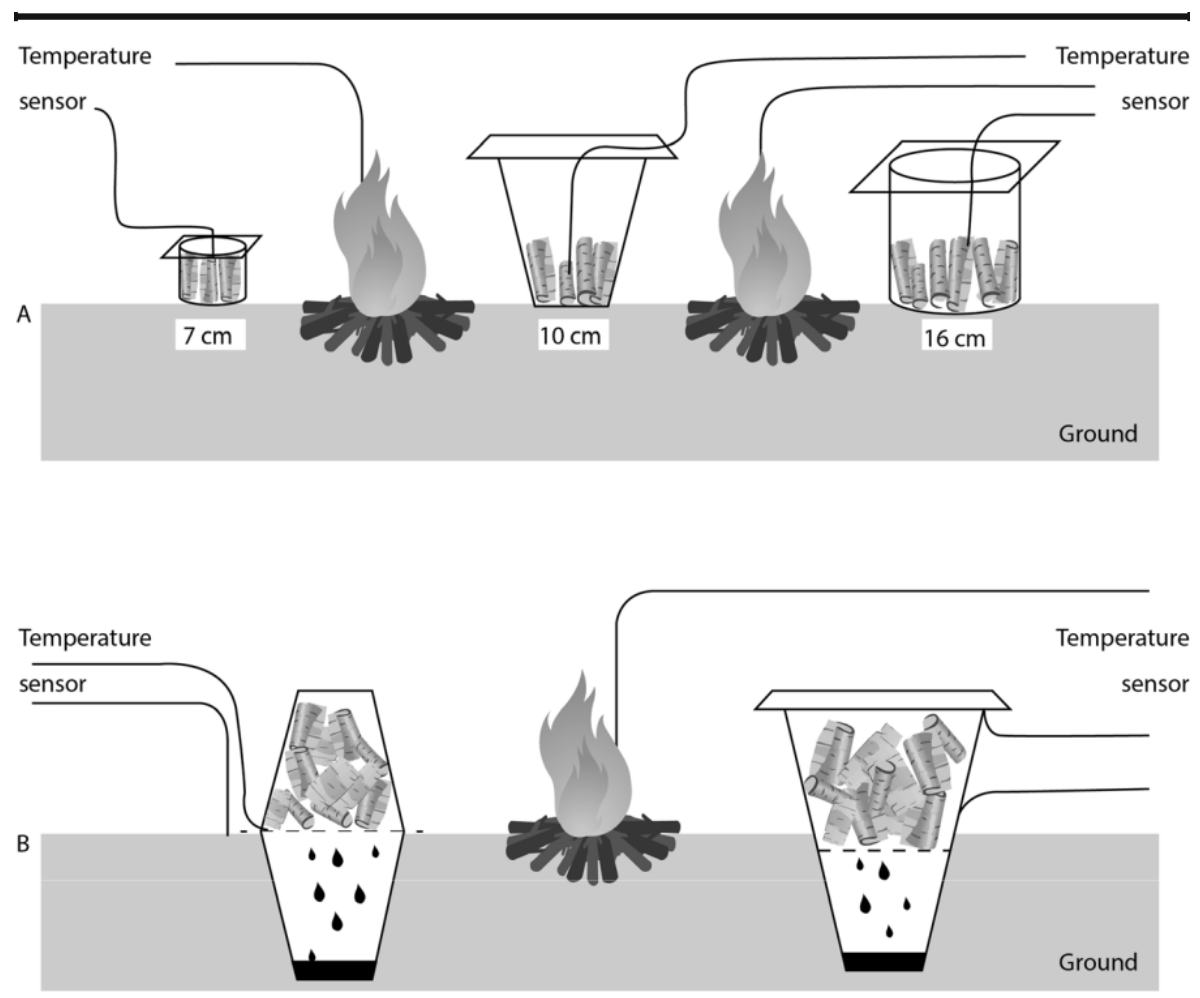

Figure 4 - Experimental manufacturing in the open-air setting. a Single-pot process (diameter of pots at base: 7, 10 and $16 \mathrm{~cm}$, respectively), b double-pot process.

\section{Laboratory Experiments to Guide Outdoor Experiments}

Preliminary laboratory experiments were carried out in test tubes sealed with aluminium foil, using a bench burner $(n=2)$. Our aim was (1) to investigate the chemical composition of the first exudation of the tar and (2) to determine the heating parameters (temperature, heating time) that would allow the initiation of bark transformation into tar. Similar laboratory tests performed to date have reported results showing a great variability (Charters et al. 1993; Aveling and Heron 1998; Sauter et al. 2000; Regert et al. 2006). Our experiments in test tubes using fresh supple and smooth barks showed the formation of a volatile yellow liquid at around $300^{\circ} \mathrm{C}$, with the exudate becoming yellow-brown at $350{ }^{\circ} \mathrm{C}$ and a black tar appearing after a further 10 min of constant heating.

These temperature data were applied to the single-pot method tested in the laboratory using a muffle furnace $(n=20)$. Here again, the objective was to evaluate the most favourable heating parameters to produce birch bark tar using this process. Maximum temperatures applied to the vessel varied from 345 ${ }^{\circ} \mathrm{C}$ up to $500{ }^{\circ} \mathrm{C}$ inside the pot with a heating time ranging from 40 to $120 \mathrm{~min}$. The amount of bark used for each experiment ranged between 6 and $150 \mathrm{~g}$, mainly depending on the size of pots (diameter: 7 or $16 \mathrm{~cm}$ ). Supple and smooth barks (10 experiments; AA-grade), barks with internal warts (8 experiments; A-grade), barks with a lot of external warts (1 experiment) and degraded barks (1 experiment; B-grade) were tested. Barks were placed as aerated chips (12 experiments) or in form of tightened-up rolls (8 experiments) inside the ceramic pot.

Under these laboratory conditions we only obtained birch bark tar when the barks were placed in the vessel as rolls and when heating was not too high (temperature remained $<500^{\circ} \mathrm{C}$ ). Thus, for the outdoor experiments we systematically arranged bark as rolls and used temperatures of $<500{ }^{\circ} \mathrm{C}$. 
Outdoor Experiments in Open-Air Fireplaces

The first outdoor experiment was to test the single-pot method in open-air fireplaces on the ground $(\mathrm{n}=$ 13). Between 10 and $118 \mathrm{~g}$ of bark was used in each experiment, depending on the occupancy rate and the size of the pot. AA- (9 experiments), A- (3 experiments) and B-grade barks (1 experiment) were used for these experiments. Barks were placed in the vessel as tied rolls. Temperature sensors were placed both inside the pot and directly in the fireplace. The vessels were removed from the fireplaces as soon as the inner temperature reached around $400{ }^{\circ} \mathrm{C}$ (from 20 to $40 \mathrm{~min}$ ). Table 1 summarises all of the conditions tested in the single-pot experiments.

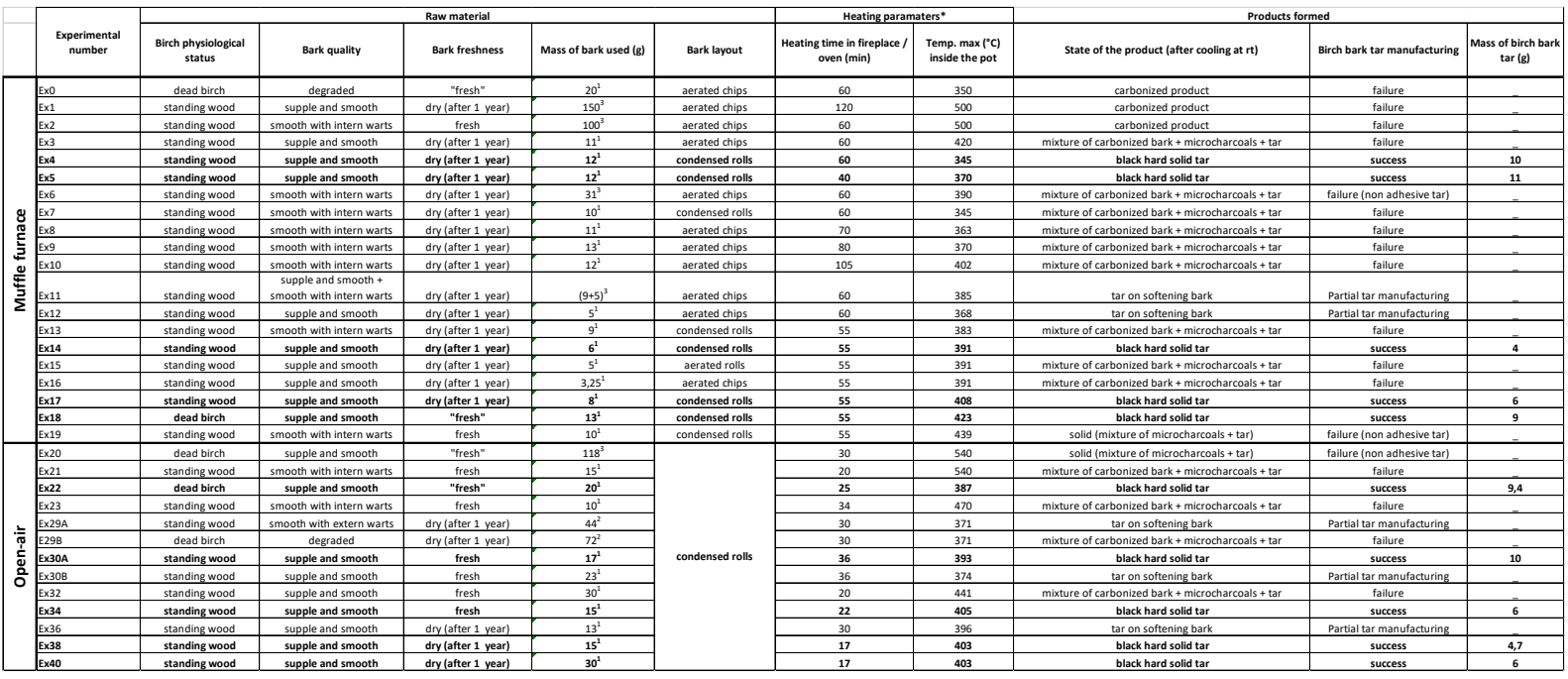

Table 1 - Simple-pot experiments tested in open air in muffle furnace. Pots of 7 (1), 10 (2) and 16 (3) cm in diameter were used. *= increase in temperatures from room temperature to maximum temperature except Ex0, Ex1 and Ex2 directly heating at maximum temperature. 
The double-pot method was tested in open-air conditions only $(n=9)$ because it was technically not possible to perform such experiments in our laboratory furnace (Table 2). The amount of bark used for each double-pot experiment was between 40 and $130 \mathrm{~g}$ depending on the size of pots (diameter 10 or 16 $\mathrm{cm})$. Most double-pot experiments $(\mathrm{n}=7$ ) were conducted using supple smooth bark (AA-grade), but barks with internal warts (Ex28B) and degraded barks (Ex27A) were also tested. Barks were placed in the form of chips inside the upper container (ceramic pot), and the second receptacle was buried underground. A fire was lit around and on the upper pot. In these experiments, tempera-tures were monitored via sensors installed in the fireplace $(n=3)$ and inside both parts of the vessel $(n=2)$. The temperatures varied from $345^{\circ} \mathrm{C}$ to $550{ }^{\circ} \mathrm{C}$ on average inside the upper container and from $100{ }^{\circ} \mathrm{C}$ to $300{ }^{\circ} \mathrm{C}$ inside the lower receptacle. The length of time in the fireplace varied, with two units (Ex37A and Ex37B) removed from the fireplace after $170 \mathrm{~min}$, six units (Ex27A, Ex27B, Ex28A, Ex31A, Ex35A, Ex35B) removed after 120- 135 min and one unit (Ex26DP) removed after 40 min.

\begin{tabular}{|c|c|c|c|c|c|c|c|c|c|c|}
\hline \multirow[b]{2}{*}{$\begin{array}{l}\text { Experimental } \\
\text { number }\end{array}$} & \multicolumn{5}{|c|}{ Raw material } & \multicolumn{2}{|c|}{ Heating paramaters } & \multicolumn{3}{|c|}{ Products formed } \\
\hline & $\begin{array}{l}\text { Birch physiological } \\
\text { status }\end{array}$ & Bark quality & Bark freshness & Mass of bark used (g) & Bark layout & $\begin{array}{l}\text { Heating time in } \\
\text { fireplace (min) }\end{array}$ & $\begin{array}{l}\text { Average temp. } \\
\text { ('C) }\end{array}$ & $\begin{array}{l}\text { State of the product (after } \\
\text { cooling at rt) }\end{array}$ & $\begin{array}{l}\text { Birch bark tar } \\
\text { manufacturing }\end{array}$ & $\begin{array}{c}\text { Mass of birch } \\
\text { bark tar (g) }\end{array}$ \\
\hline Ex26dp & dead birch & supple and smooth & "fresh" & $40^{2}$ & \multirow{9}{*}{ bark chips } & 40 & \multirow{9}{*}{345 to 550} & viscous liquid tar & beginning of reaction & 3 \\
\hline Ex27A & dead birch & degraded & dry (after 1 year) & $265^{2}$ & & 135 & & & failure & \\
\hline Ex27B & dead birch & supple and smooth & "fresh" & $70^{2}$ & & 135 & & viscous liquid tar & success & 20,5 \\
\hline Ex28A & standing wood & smooth with intern warts & dry (after 1 year) & $71^{2}$ & & 120 & & viscous liquid tar & success & 6 \\
\hline Ex31A & dead birch & supple and smooth & "fresh" & $130^{2}$ & & 125 & & viscous liquid tar & success & 28,5 \\
\hline Ex35A & standing wood & smooth with extern warts & fresh & $67^{2}$ & & 125 & & viscous liquid tar & success & \\
\hline Ex35B & standing wood & smooth with wood residues & fresh & $166^{2}$ & & 125 & & viscous liquid tar & success & \\
\hline Ex37A & standing wood & supple and smooth & fresh & $75^{2}$ & & 170 & & high viscous liquid tar & success & 18,7 \\
\hline Ex378 & standing wood & supple and smooth & fresh & $130^{3}$ & & 170 & & high viscous liquid tar & success & 40 \\
\hline
\end{tabular}

Table 2 - Double-pot experiments tested in open air. Pots of 10 (2) and 16 (3) cm in diameter were used.

\section{Chemical Analysis of Experimental and Archaeological Birch Bark Tars}

Sample preparation and GC and GC-MS analyses were performed using the method described by Rageot et al. (2016). Briefly, the sample was ground and then extracted in high-performance liquid chromatography-grad dichloromethane $\left(1 \mathrm{mg} \mathrm{mL}{ }^{-1}\right.$ for experimental tars and $4 \mathrm{mg} \mathrm{mL}^{-1}$ for archaeological samples). Extraction was carried out by ultrasonication for $30 \mathrm{~min}$. The extracts were derivatised by adding $50 \mu \mathrm{L}$ of BSTFA and $4 \mu \mathrm{L}$ of pyridin. A volume of $1 \mu \mathrm{L}$ of this solution was analysed by GC and GC-MS.

GC analyses were performed on an Agilent 7890A gas chromatograph (Aglilent Technologies, Santa Clara, CA, USA) equipped with an on-column injection system.

GC-MS analyses were performed using a Shimadzu QP2010 ultra gas chromatograph- mass spectrometer with a split/splitless injection system operating in the splitless mode (purge flow of 2.0 $\mathrm{mL} / \mathrm{min}$ and split ratio of 3.0) (Shimadzu Corp., Kyoto, Japan). Both systems were equipped with an Agilent J\&W DB-5MS column (30 $\mathrm{m} \times 0.25 \mathrm{~mm}$ i.d.; film thickness $0.25 \mu \mathrm{m}$ ); the inlet temperature was set at $300{ }^{\circ} \mathrm{C}$. The oven temperature was ramped from $50{ }^{\circ} \mathrm{C}$ (held isothermal for $2 \mathrm{~min}$ ) to $150{ }^{\circ} \mathrm{C}$ at $10^{\circ} \mathrm{C} / \mathrm{min}$, then increased to $320^{\circ} \mathrm{C}$ at $4{ }^{\circ} \mathrm{C} / \mathrm{min}$ (held isothermal for $15 \mathrm{~min}$ ). GC analysis was carried out using hydrogen as the carrier gas, with a constant column head pressure of $16 \mathrm{psi}$; the temperature of the flame ionisation detector was $340{ }^{\circ} \mathrm{C}$. GC-MS analyses were carried out using helium as the carrier gas, and mass spectra were acquired using electron ionisation at $70 \mathrm{eV}$. Masses were scanned from m/z 50 to 950 in $0.6 \mathrm{~s}$. The ion source and transfer line temperatures were set at $200{ }^{\circ} \mathrm{C}$ and 250 ${ }^{\circ} \mathrm{C}$, respectively. Mass spectra were matched against those of authentic standards (betulin, betulinic acid, lupeol, lupenone, oleanolic acid and $\beta$-amyrin) using published data (Binder et al. 1990; Hayek et al. 1990; Aveling and Heron 1998; Regert et al. 1998; Garnier 1999; Lavoie 2001; Rageot 2015) or commercial MS libraries (National Institute of Standards and Technology, 2008 edition). 


\section{Results of Experimental Manufacturing}

The experiments performed allowed us to examine the influence of several parameters on the production of birch bark tars and on their resulting properties.

On the whole, we demonstrated that the double-pot system requires a less strict control of temperature and bark quality than the single-pot process, as illustrated by the number of successful experiments in outdoor conditions: 89\% (double-pot) versus 38\% (single-pot). The double-pot system produces a viscous liquid tar while the single-pot system, when successful, provides a tar that is solid and hard at room temperature. The fibrous residues remaining in the upper container may certainly explain why double-pot systems lead to a lower yield than single-pot systems.

Having set out the main differences between the systems of production, in the following sections we discuss in more detail the role of each parameter tested.

\section{Single-Pot Experiments}

The 20 experiments conducted in the laboratory enabled us to determine the best parameters for the production of birch bark tar and the potential classification of the resulting products. Experiments were considered to be successful when a black alveolar substance with the consistency and aspect of a foam that generally turned into a solid hard material after cooling was obtained. When no tar was produced (unsuccessful experiments), the result of the transformation of bark with heating was a black, solid, carbonised and brittle substance consisting of micro-charcoal and ash. The formation of a tiny amount of tar on soft bark occurred during the so-called "partial tar manufacturing". However, the reaction was not complete and the tar was difficult to use as adhesive.

In summary, regarding the laboratory experiments: five were successful (25\%, Ex4, Ex5, Ex14, Ex17 and Ex18); 13 failed (Table 1); and two were partially successful (formation of a small amount of tar within the bark residue-Ex11 and Ex12). The number of successful experiments (5 of 13: Ex22, Ex30A, Ex34, Ex38 and Ex40) was improved under outdoor conditions based on the experience gained from laboratory tests. Table 1 presents the parameters tested and the results obtained.

We showed that the right combination of several parameters was essential for manufacturing birch bark tar. Two of these parameters are the use of AA-grade bark and the proper layout of the bark within the container (Ex4, Ex5, Ex14, Ex17, Ex18, Ex22, Ex30A, Ex34, Ex38 and Ex40). It was not possible to produce tar with aerated chips of bark and with wart-containing barks. Bark quality had thus a considerable impact on the formation of tar. To our knowledge, this is the first time that this parameter is taken into account and discussed with regards to birch bark tar production. In contrast, the role of bark freshness is less important since tar could be equally obtained with bark from standing or dead trees and therefore from fresh and dried barks, as confirmed during outdoor experiments. Birch bark tar was produced from 1-year-old dried barks harvested from standing wood (Ex4, Ex5, Ex14, Ex17, Ex38, Ex40), from fresh bark collected on dead trees (Ex18) and from fresh bark from standing wood (Ex22, Ex30A, Ex34).

A third parameter of crucial importance in the process of tar production with single-pot systems are thermal conditions (temperature and time). The muffle furnace experiments Ex0, Ex1 and Ex2 showed that a carbonised product is obtained if the bark is exposed to high temperatures for a long time (from $350{ }^{\circ} \mathrm{C}$ for $>60 \mathrm{~min}$ ). The experiments in the muffle furnace were successful when the pots were taken out of the oven once smoke was detected, at around $400{ }^{\circ} \mathrm{C}$ (from $345^{\circ} \mathrm{C}$ to $423{ }^{\circ} \mathrm{C}$ ) for a heating time of 55-60 min. It was more difficult to control the temperature increase in the outdoor experiments, especially when trying to apply slow heating. The inner temperature monitoring of outdoor single-pot experiments (Figure 5) indicated that vessels have to reach a maximum temperature of about $400{ }^{\circ} \mathrm{C}$ to produce a useable birch bark tar (Ex22, Ex30A, Ex34, Ex38 and Ex40) but should not exceed $430{ }^{\circ} \mathrm{C}$ (Ex20, Ex21, Ex23 and Ex32). Moreover, these optimal temperatures have to be reached within a specific heating time period, which is probably linked to the mass and the concentration of the bark in the pot, otherwise the reaction is not complete (Figure 5). 
These results allowed us to conclude that good temperature control combined with the use of highquality bark placed in tied rolls in the container are the conditions necessary to obtain birch bark tar with using the single-pot method.

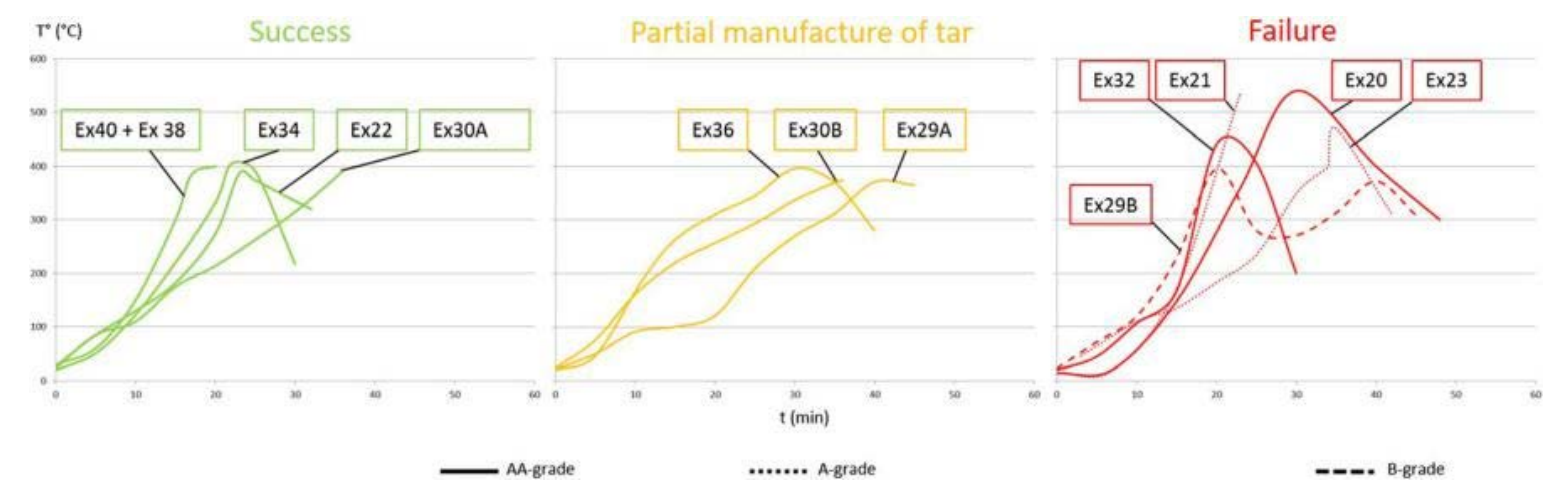

Figure 5 - Measurement curves of temperature (inside the pot) during the experimental manufacturing of birch bark tar using a single-pot system set in the fireplace.

In order to determine the possibility of recycling this material and to study the changes in the tar following re-heating in open-air conditions, we reheated the tar (Ex5A) at $200{ }^{\circ} \mathrm{C}$ for $20 \mathrm{~min}(\mathrm{Ex} 5 \mathrm{~B})$. The consistency and aspect of a foam was again obtained before it once again changed into a solid hard material after cooling.

\section{Double-Pot Experiments}

The number of successful experiments increased significantly using the double-pot system (Table 2), with birch bark tar obtained from eight of nine attempts using either AA-grade bark $(n=7)$ or A-grade bark $(n=1)$. The experiment using B-grade bark was the only one totally unsuccessful (Ex27A). However, it should be noted that only a beginning of the reaction was observed in the shortest experiment (Ex26DP, $40 \mathrm{~min}$ in the fireplace).

In the successful experiments, a black and viscous substance that could be easily spread over any surface was obtained. The substance remained viscous after cooling down to room temperature, with the exception of those experiments with a long heating time (Ex37B and Ex37A), for which the tar hardened. However, a solid material was achieved at room temperature from sample Ex37B following re-heating in the open-air environment at $300^{\circ} \mathrm{C}$ for $20 \min$ (Ex37B2).

From these results it would appears that the control of temperature is not as crucial in the double-pot system of birch bark tar production as it is in single-pot production. Whatever the maximum temperature (range $345-550{ }^{\circ} \mathrm{C}$ in the upper pot) and the temperature ramp used, birch bark tar was systematically obtained. Bark quality does not seem to be important except in the case of degraded bark, although this possibility has to be considered cautiously at this stage of the study since only one experiment was performed with B-grade barks.

\section{Comparison of Birch Bark Tar Production Using Single-Pot and Double-Pot Systems}

To our knowledge, the single-pot and double-pot systems of birch bark tar production have never been compared, even though the characteristics of each system had a great impact on the success of experiments, and also on both the quality and yield of the final product. Our results show that the production of birch bark tar with the double-pot system is clearly less sensitive to thermal control and bark quality than the single-pot method. This lack of sensitivity to these two parameters may be explained by the fact that the tar obtained is not exposed to high temperature since, as soon as it forms, it flows from the upper pot to the lower receptacle that is not in direct contact with fire. 
Our experiments also showed that birch bark tar manufacturing using single-pot system is the faster of the two systems. However, in the single-pot system, bark has to be placed in form of highly condensed rolls inside the pot. A rapid increase of temperature up to $300{ }^{\circ} \mathrm{C}$ initiates the transformation. Lastly, the pot has to be removed from the fireplace at about $400^{\circ} \mathrm{C}$. The hypothesis that ancient populations used an odoriferous indicator has been suggested by several authors. For example, the well-known "Russian leather" scent usually attributed to birch extracts, possibly resulting from the volatilisation of suberin phenolic compounds, was detected during our laboratory experiments with the single-pot system. If the time interval between first odour emission and removal of the pot from the oven was too long after this odour emission, the resulting tar was carbonised. Therefore, such a system, which seems easier to set up than the double-pot system, requires better control of several parameters.

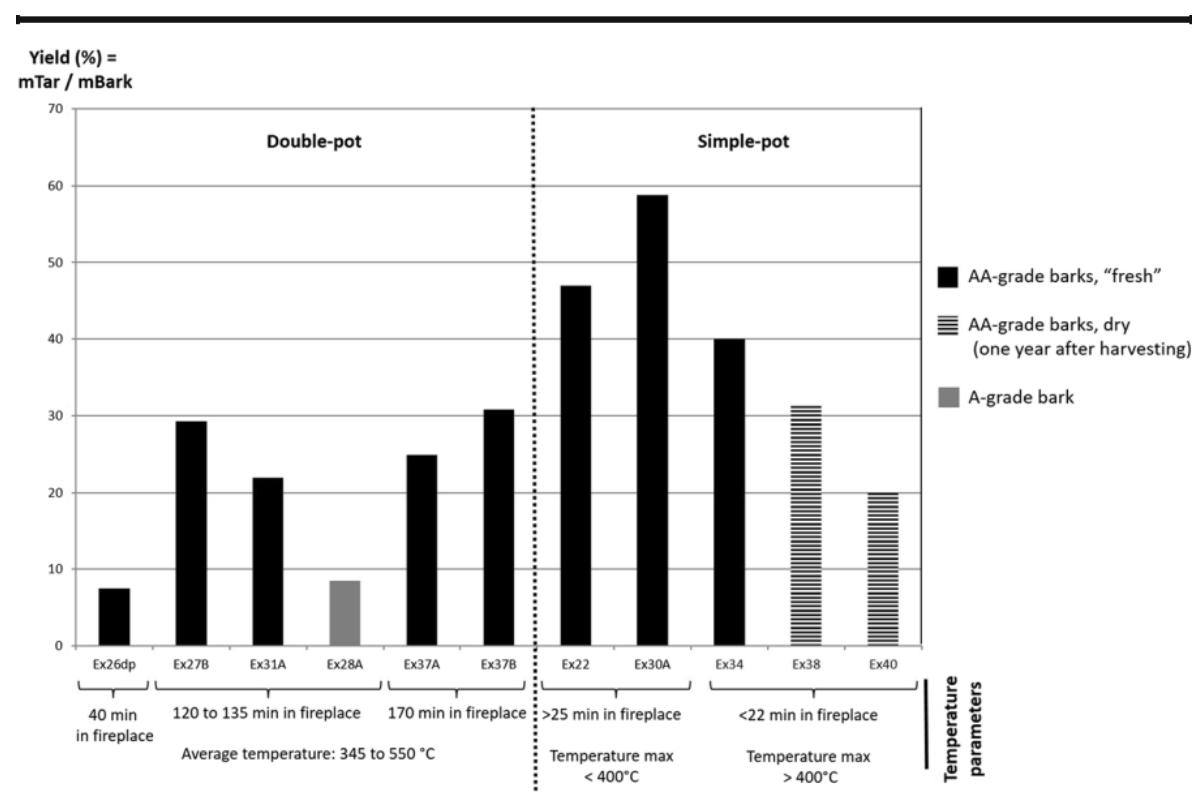

Figure 6 - Yields of birch bark tar produced either by single/(simple)- and double-pot processes in outdoor conditions.

Yields of tar production (= ratio of tar mass/bark mass) using single-pot systems was very high in the five successful experiments performed in the laboratory (between 67 and 92\%). Differences could not be clearly explained according to the different parameters. Yields were lower for the five successful experiments run in open fireplace, i.e. between 20 and 59\%, as presented in Figure 6 . Moreover, the use of fresh bark combined with a slower temperature progression seemed to afford better yields. In the case of the double-pot systems, yields of tar production (Figure 6) were on average lower than those for the single-pot experiments (7.50-31\%) since large amounts of fibrous residues remained in the upper container. Two experiments could not be integrated in this calculation (Ex35A and 35B) due to the loss of some tar caused by a leak in the buried pot. Among the other successful experiments, the lowest ratios logically corresponded to the partial transformation (Ex26DP, 7.50\%) but also to the experiment using A-grade bark (Ex28A, 8.45\%). Yields of the four other double-pot experiments are rather similar (between 22 and 31\%). 


\section{Chemistry of Experimental Birch Bark Tars: What Is the Effect of Heating on the Molecular Biomarkers?}

The different types of experimental tars produced were analysed by GC-MS to assess potential relationships between chemical composition and the conditions under which the tars were produced. A large number of molecular compounds were identified in the experimental tars, some of which for the first time.

Triterpenes were identified in all experimental tars produced; fatty acids were detected in tars produced by per descensum processes and more volatile molecules such as phenolic compounds or naphthalenes were present in the first exudation. The most volatile chemical families are the least significant from the archaeolog-ical point of view and therefore not analysed further in our study. Depending on the amount of each chemical family in the sample and on the ratio of terpenoid biomarkers to degradation markers, it was possible to establish relationships between chemical compositions and the manufacturing process.

\section{Identification of Molecular Constituents}

Pentacyclic triterpenes such as betulin, lupeol, erythrodiol and betulinic acid, which are the main BM naturally present in the bark of Betula pendula (Krasutsky 2006), were identified in most of the tars produced. These compounds are considered to be natural/initial BM of birch bark. Betulinic acid was not detected in the tars produced in the single-pot experiments. Other BM naturally present in birch bark were also identified in the tar from the first exudation (FE1), such as oleanolic acid, oleanolic acid 3acetate and $\beta$-amyrin (Ekman 1983; Krasutsky 2006).

We also identified various molecular markers that resulted from the transformation of these native BM. Depending on the conditions and mechanisms of formation, these degradation markers were classified into two main categories: markers of soft heating and markers of strong heating, respectively, with the latter category further subdivided into two subclasses, one corresponding to double-degraded pentacyclic triterpenes (DPT) and the other to hydrocarbon pentacyclic triterpenes (HPT).

\section{Soft Heating Markers (Triterpenes)}

Markers of soft heating, such as betulin 28-acetate, betulinic acid methyl ester, allobetulin, betulone, erythrodiol ester derivative (b447), oleanol derivative (b418), lupa-2,20(29)-dien-28-oic acid, oleandien-28-oic acid, lupa-2,20(29)-dien-28-ol, $\alpha$-betuline I, lupa-2,20(29)-diene, lupa-2,20(29)-dien28-ol, betulone and lupa-2,20(29)-dien, were found in all experimental tars, including those derived from the first exudations. These markers result from the heating treatment of birch bark under soft temperature conditions, although some of them [lupa-2,20(29)-diene, lupa-2,20(29)-dien-28-ol and betulone] are also known to be formed by natural decay within the sedimentary matrix, as shown by the previous analyses of archaeological bark from neolithic sites (Aveling and Heron 1998; Garnier 1999). Due to their possible double origins in the archaeological context, they cannot be used as indicators of the different systems of production but the ratio between biomarkers and these degradation markers may be used as an indicator of the degree of preservation of the initial biomarkers of bark. Thus, an indicator of natural degradation, referred to as ID and calculated as follows, was used in this work: ratio [lupa2,20(29)-dien-28-ol + betulone]/betulin. As betulin can be degraded by oxidation and dehydration following heating, the ID was first calculated for experimental tars to create a reference value for experimental birch bar tar. 


\section{Markers of Strong Heating (Triterpenes)}

We defined "strong heating markers" as triterpenoid molecular compounds that were absent from the first exudation experiments but formed during single-pot and double-pot process.

The main markers identified in this category are DPT and HPT [except for lupa-2,20(29)-diene]. The DPT compounds (3-oxo-allobetulane; 28-oxoallobetul-2ene; $\alpha$-olean-28-al; allobetul-2-ene; $\alpha$ allobetulin I) mainly result from cycloisomerisation on cycle $\mathrm{E}$ and alcohol degradation on cycle $\mathrm{A}$ of betulin and betulinic acid. This reaction hardly ever occurs in nature because it requires heating under acidic conditions ( $\mathrm{Li}$ et al. 1998). HPT, such as compound b386, or $\alpha$-hydrocarbon pentacyclic triterpenes, such as compounds b360 and $\alpha$-lupane, represent the second category of strong heating markers which were also identified in high quantity following the heating treatment. They can sometimes result from rearrangement on cycle A, such as $\alpha$-lupane (Figure 7). Such triterpenes were detected by mass spectrometry from their characteristic peaks of their lupane (m/z 189 and 203) and oleanane families (m/z 190) (Rageot 2015; Electronic Supplementary Material [ESM] Table S1).

\section{Fatty Acids}

Unsaturated and saturated fatty acids with an even and odd number of carbon atoms from C16 to C22 were only identified in significant amounts (from 3 to $17 \%$ of the soluble fraction) in tars produced by per descensum processes (double-pot process and in the first exudation). They were absent (Ex38 and Ex40) or present in only a trace amount (Ex22, Ex30A, Ex5B/5A) in tars produced by the single-pot process. Fatty acids arise from the degradation of the suberic polymer of the bark (Ukkonen and Erä 1979; Ekman 1983). Diacids with an even and odd number of carbon atoms from C16 to C22 were only identified in some tars made using per descensum processes; these are also probably derived from the suberic polymer.

The presence of behenic acid $\mathrm{C}_{22: 0}$ ) as a major saturated fatty acid combined with odd-numbered fatty acids (in particular $\mathrm{C}_{21: 0}$ ) and diacids (in particular D21 and D22) is rather rare in natural substances. This molecular assemblage can thus be used as a marker of birch bark transformation under specific heating conditions, such as per descensum processes (Figure 8).

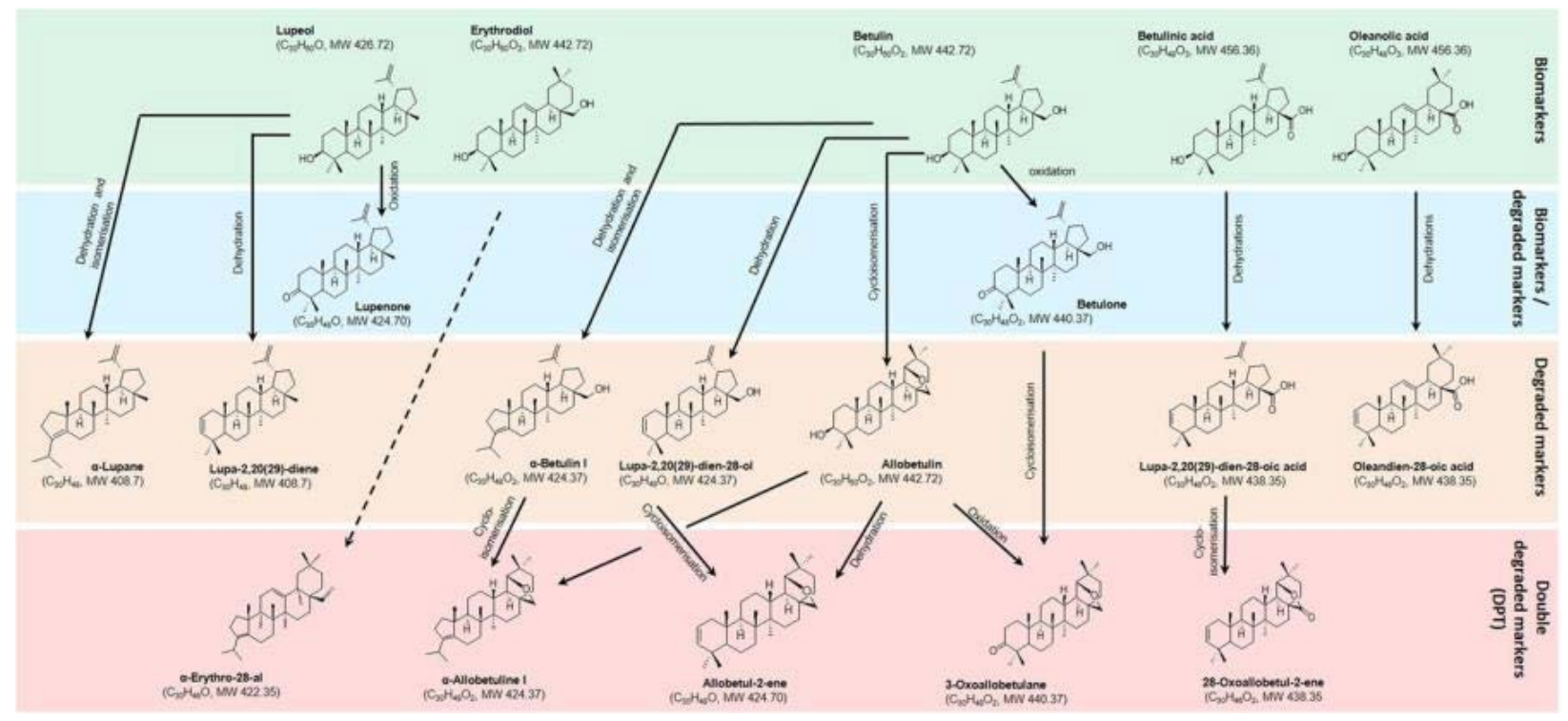

Figure 7 - The main biomarkers from Betula pendula and their degraded products formed during tar production. 


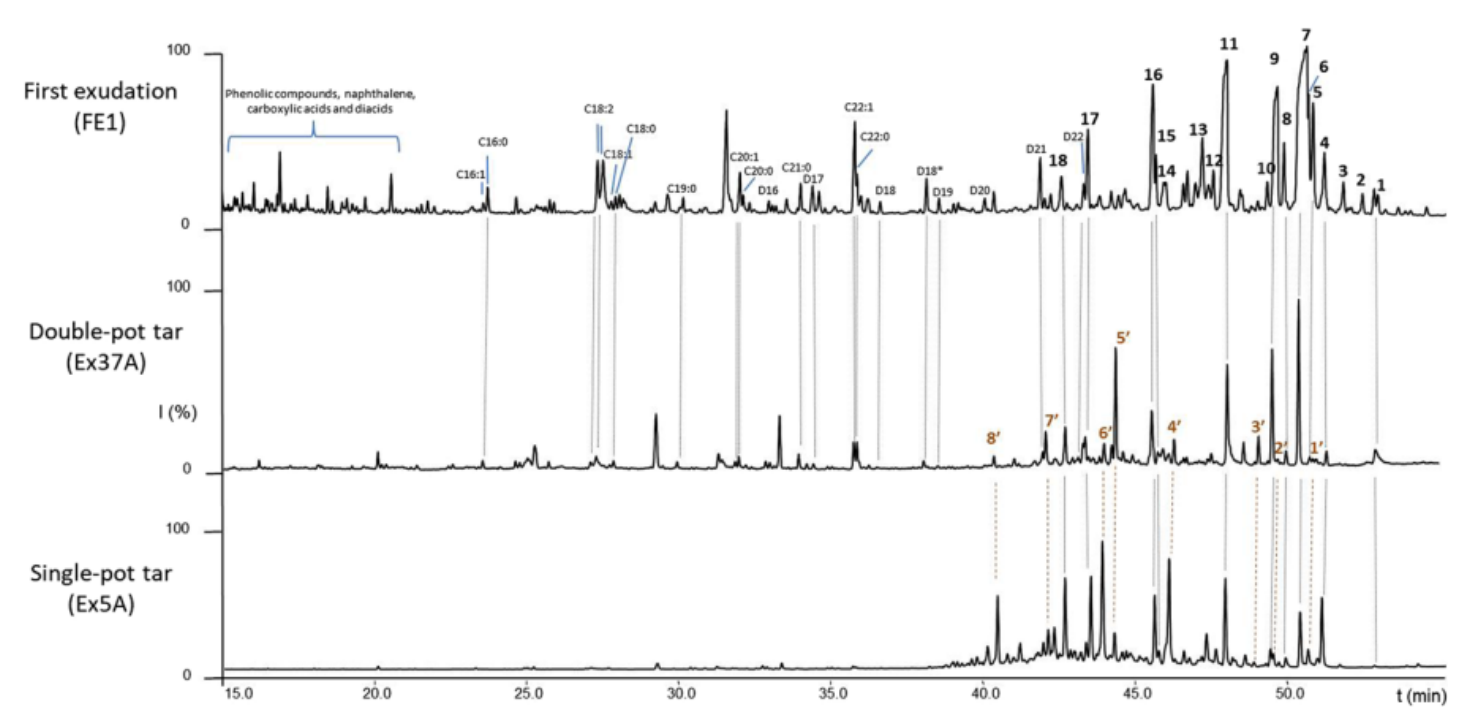

Figure 8 - Analysis of experimental birch bark tar samples by gas chromatography. Terpenes that are biomarkers and soft-heating markers are shown as peaks 1-18: 1, betulin 28-acetate; 2, betulinic acid methyl ester; 3, betulinic acid 3-acetate; 4, allobetuline; 5, betulinic acid; 6, oleanolic acid; 7, betulin; 8, betulone; 9, b447 (erythrodiol ester derivative); 10, erythrodiol; 11, lupeol; 12, b418 (oleanol); 13, $\beta$-amyrin; 14, [lupa-2,20(29)-dien-28-oic acid]; 15 , oleandien-28-oic acid; 16, lupa-2,20(29)-dien-28-ol; 17, $\alpha$-betuline I; 18; lupa-2,20(29)-diene. Terpenes only found in tar produced from the single- and double-pot processes, respectively, and are strong heating markers are shown as peaks 1'-8': 1', 3-oxo-allobetulane; 2', 28-oxoallobetul-2ene; 3', $\alpha$-olean-28-al; 4', allobetul-2-ene; 5', b386 (hydrocarbon triterpene); 6', $\alpha$-allobetuline I; 7', b360 ( $\alpha$-hydrocarbon triterpene; 8', $\alpha$-lupane. Cx:y Fatty acids with $\mathrm{x}$ carbon atoms and $\mathrm{y}$ unsaturations, $\mathrm{D}$ diacids

\section{Relationships between Molecular Signature and Systems of Production}

The results showed that it is possible to distinguish between the different tar production processes based on molecular criteria (Figures 8, 9, 10, and 11). Among the successful experiments, we chemically investigated five samples from single-pot systems and six samples from double-pot systems. The samples were first classified into different categories according to the method of pro-duction and the temperature parameters:

1 - The first exudations of birch bark produced in the laboratory (FE1)

2 - Tars produced using single-pot (SP) methods:

a) with a fast temperature increase (from room temperature to about $400{ }^{\circ} \mathrm{C}$ in less than $20 \mathrm{~min}$; $\mathrm{SPa}=\mathrm{Ex} 38$ and Ex40)

b) with a slow temperature increase (from room temperature to about $400{ }^{\circ} \mathrm{C}$ in more than 20 min; SPb = Ex22, Ex30A, Ex5B/5A).

3 - Tars produced using double-pot (DP) methods:

a) with a short heating time ( $\leq 135 \mathrm{~min}$ in outdoor fireplace; DPa = Ex26DP, Ex27B, Ex28A and Ex31A)

b) with a long heating time (170 min in outdoor fireplace; $\mathrm{DPb}=\mathrm{Ex} 37 \mathrm{~A}$ and Ex37B) 


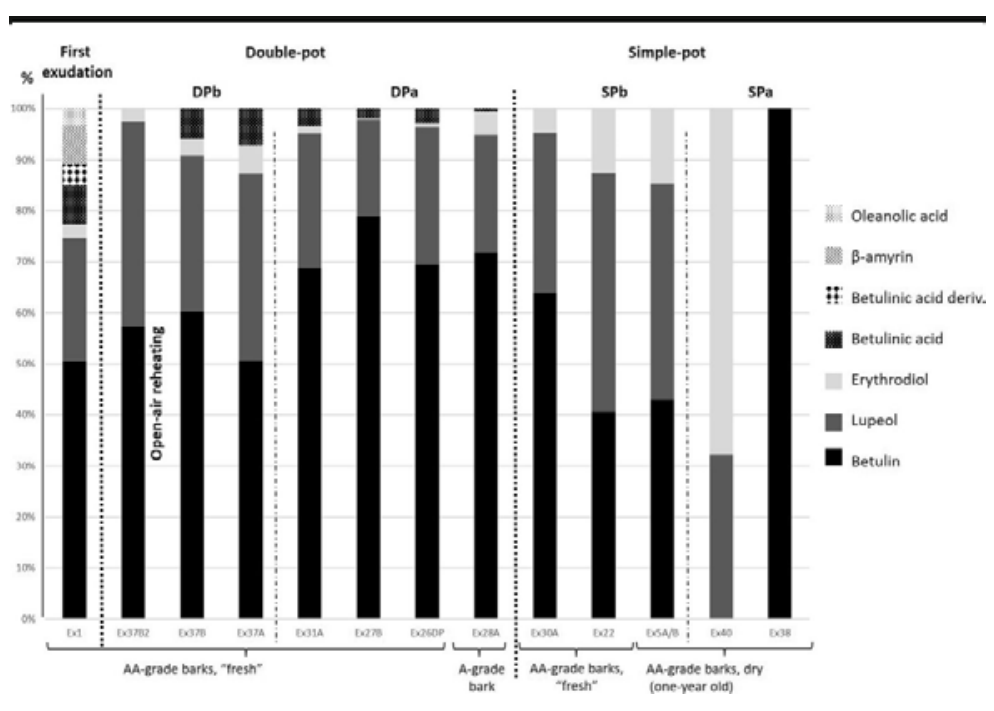

Figure 9 - Comparison of biomarker content in the experimentally produced birch bark tars. DP Double-pot system with a short heating time (DPa) and a long heating time (DPb), SP simple/single-pot system with a fast temperature increase (SPa) and a slow temperature increase (DPb). For details see text.

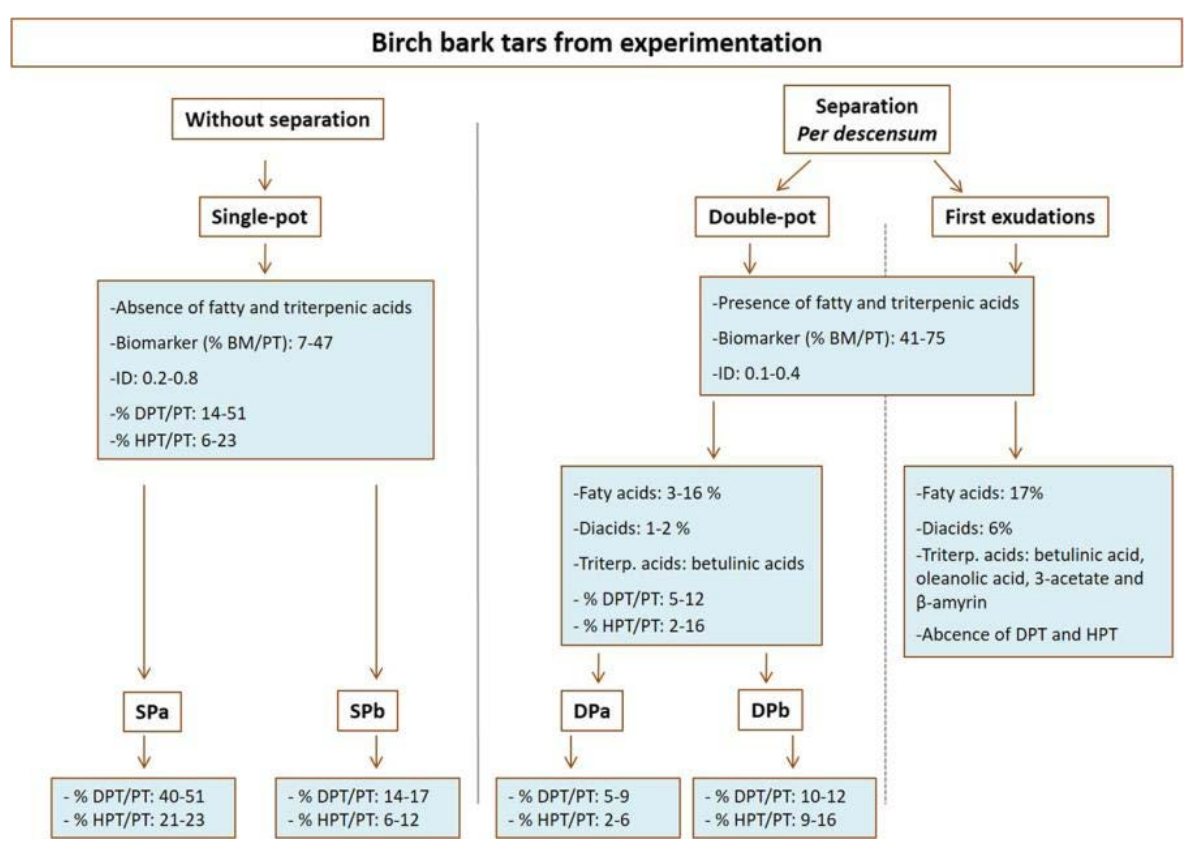

Figure 10 - Synthesis of molecular criteria used to distinguish the system of production. DPT Double-degraded pentacyclic triterpenes, HPT hydrocarbon pentacyclic triterpenes, ID indicator of degradation. 


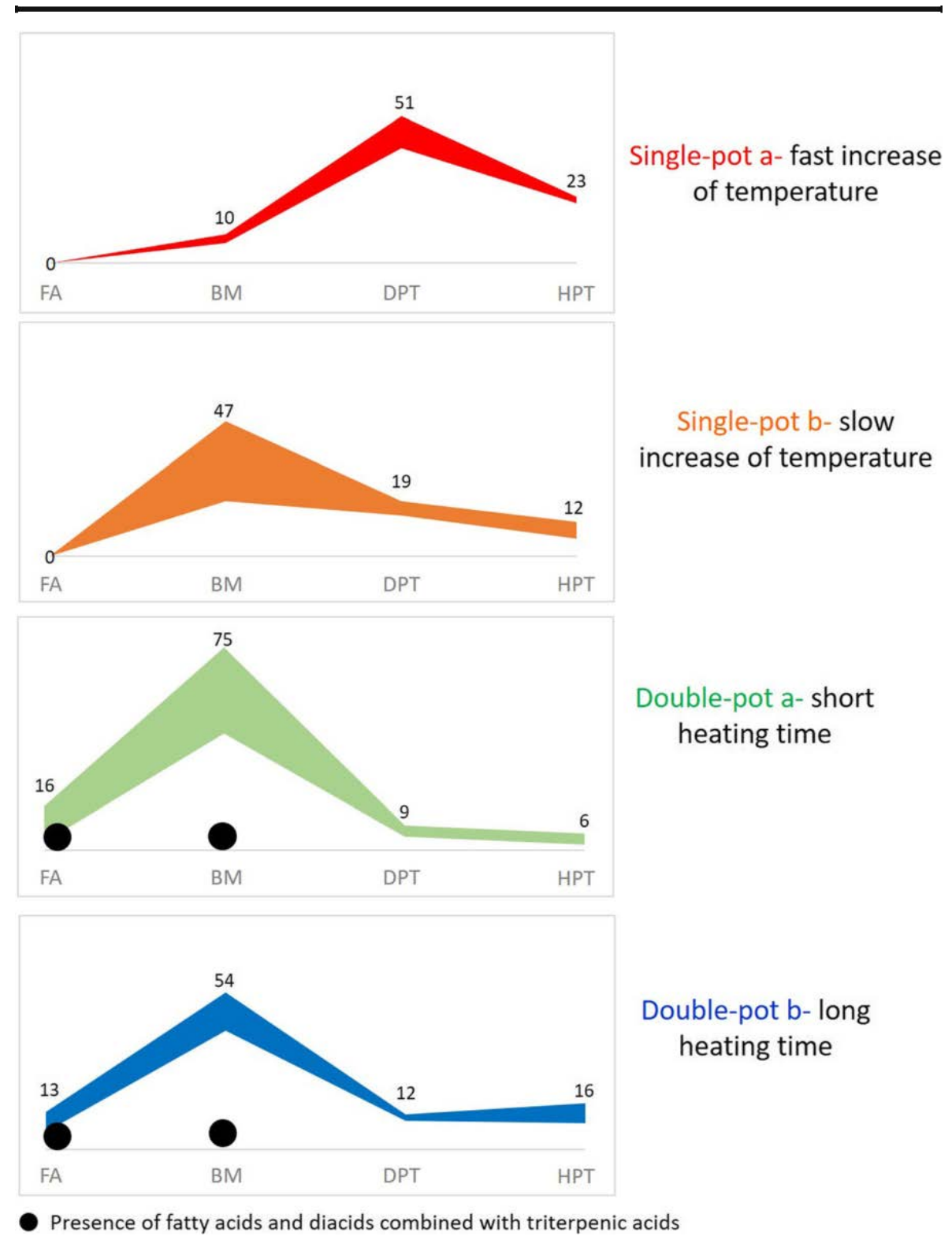

Figure 11 - Comparison of experimental tars based on main molecular components. FA Fatty acids, BM biomarkers.

The presence of both fatty acids and triterpenic acids are specific to per descensum processes. These compounds are not identified in tars produced in single-pot systems. Triterpenoid biomarkers vary quantitatively depending on the production process (Figure 9), and on average they are more abundant in tars produced by per descensum methods, including first exudation and double-pot systems (41-75\% triterpenes), than in tars produced in single-pot systems (7-47\% of triterpenes). Among per descensum processes, first exudations can be distinguished from tar from double-pot systems by their larger number of biomarkers (in particular oleanolic acid, oleanolic acid 3-acetate and $\beta$-amyrin). ID values also show a higher degradation of biomarkers in single-pot tars (ID 0.2-0.8) than in per descensum tars (ID 0.10.3 ). Tars produced in single-pot systems contain on average a higher quantity of strong heating markers (DPT $=14-51 \%$ and HPT $=6-23 \%$ triterpenes) than those obtained using double-pot systems (DPT = $5-12 \%$ and HPT $=2-16 \%$ triterpenes). Strong heating markers (DPT and HPT) were not identified in first exudations (Figure 10). 
Molecular differences were also observed according to the heat treatment within both systems (Figure 11). With regard to single-pot systems, tars formed after a slow temperature increase present fewer heating markers (DPT $=14-17 \%$ and HPT $=6-12 \%$ of triterpenes) than those resulting from a fast temperature increase (DPT $=40-51 \%$ and HPT $=21-23 \%$ of triterpenes). In double-pot tars, markers of strong heating are less important in proportion when the heating time is short (DPT $=5-9 \%$ and HPT $=2-6 \%$ of triterpenes) than with prolonged exposure to heat (DPT $=10-12 \%$ and HPT $=9-16 \%$ of triterpenes).

Finally, we analysed tars produced in both the single-pot and double-pot systems, reheated in open-air and found that there was no significant molecular change following the open-air reheating of single-pot samples (Ex5A and Ex5B) and observed only a few differences for most molecular markers in the double-pot samples (Ex37B and Ex37B2). However, it is notable that betulinic acid could no longer be identified and its ID value had increased (0.15 to 0.18 ). We also found a decrease in $\alpha$-triterpenes and diacids and an increase in the proportion of fatty acids. Therefore, in terms of interpreting archaeological data, we recommend cautions with respect to these compounds.

\section{Archaeological Inference: Birch Bark Tar from the Neolithic Site of Nice-Giribaldi (France)}

In order to assess the feasibility of distinguishing different ways of production using biomolecular markers, we chose the Neolithic site of Nice-Giribaldi, exca-vated in the 1980s by one of us (DB) at Nice in the south-east of France, on which a large amount of birch bark tar was discovered and previously identified (Binder et al. 1990; Regert 1996; Regert et al. 2000).

\section{Archaeological Context and Material}

The site of Giribaldi is an open air site from the Neolithic southern Chassey culture that was occupied during at least 7 centuries from 4700 to $4000 \mathrm{cal}$ BCE. Several pits were discovered, one in the south of the site (Structure [St.] 1) and four (St. 3, St. 6A, St. 6B and St. 7) in the north of the site (Binder 2004; Binder and Lepère 2014, Binder 2016). The latter four pits were the focus of our study. Different phases were distinguished among the excavated areas (relative dating and radiocarbon measures on short life remains, in particular seeds). Pre-Chassey steps (4700-4500 cal BCE) were identified in St. 1 (Phase A) and proto-Chassey-SMP2 steps (4500-4350 cal BCE) were iden-tified in St. 6B (Phase B). A first step of Early Chassey (Phase C1) was found in St. 7 and a second one, later, in St. 3 (Phase C2). The chronology of both structures is between 4375 and 4350 and between 4100 and $4050 \mathrm{cal}$ BCE, respectively. Finally, St. 6A/6 seems to be a mixture of the St. 7 and 6B (Phase B + C).

The rich archaeological layers of the studied pits (St. 3, St. 6A, St. 6B and St. 7) correspond to nonspecialised release of domestic and craft activities. Indeed, releases include high quantities of ceramic sherds, grinders and shells together with archaeobotanical and archaeozoological remains. Such materials show the reuse of the structures as a dump following a primary use, in particular clay extraction.

Among the artefacts preserved at Nice-Giribaldi, a series of brown free lumps in the sediment were discovered by flotation. Previous analyses (Binder et al. 1990; Regert 1996; Regert et al. 2000) showed that some of them contained birch bark tar. Only 15 samples were investigated in those first studies, and they lacked a thorough examina-tion and identification of the molecular markers as well as a spatial and chronological contextualisation of the materials analysed. We thus decided to reconsider the study of this collection targeting two objectives: (1) to estimate the variability of molecular composition of the samples in order to determine the manufacturing processes with precision and (2) to study the production practices during the different periods of human occupancy. 
We present here the study of 23 additional samples found in the sediment from the pit filling of including free lumps (St. 3, St. 6A/6, St. 6B and St. 7) and two residues used to haft bone assegai blades (MR6560A and MR6560B; St. 6A/6 and St. 3) (ESM Table S2).

Most of the samples were excavated from the same sedimentary matrix, which corresponds to a greybrown clay loam. Only sample MR6555 (St. 6B) comes from a red-brown clay layer. Samples come from the gradual filling of the pits following clay extraction and are thus characterised by similar burial conditions.

\section{Analytical Results}

The presence of alcohol and hydrocarbon triterpenoid markers from the lupane family, including betulin, lupeol and lupenone were detected in all samples $(n=25)$ indicating by-products of birch bark. Triterpenes, including markers of soft and strong heating, were also identified, suggesting birch bark tar production (Figure 12). Such molecular composition confirms that this material has been largely used at Nice-Giribaldi.

Within these samples, different degrees of degradation were observed, giving evidence for a variety of thermal and/or degradation processes. Figure 13 shows four different degradation patterns depending on the ID and the ratio of biomarkers (BM\%). Category 1 indicates low degradations while category 4 shows strong degradation and/ or partial carbonisation. The ID could not be calculated for the two samples of category 4 (MR6569 and MR6567), with only a few triterpenic markers observed in these samples, even as traces for MR6569.

In addition to triterpenoid alcohols and hydrocarbons, most of the samples ( $\mathrm{n}=15,65 \%)$ contain fatty acids (C18 to C22), diacids (in particular D21 and D22) and betulinic acid, which is characteristic of a system of production which excludes a single-pot system according to the experimental results previously described (Figure 13). Samples in which no fatty acid nor betulinic acid were detected could result from a system without any separation of bark from tar, especially for non-degraded tars (categories 1 and 2).

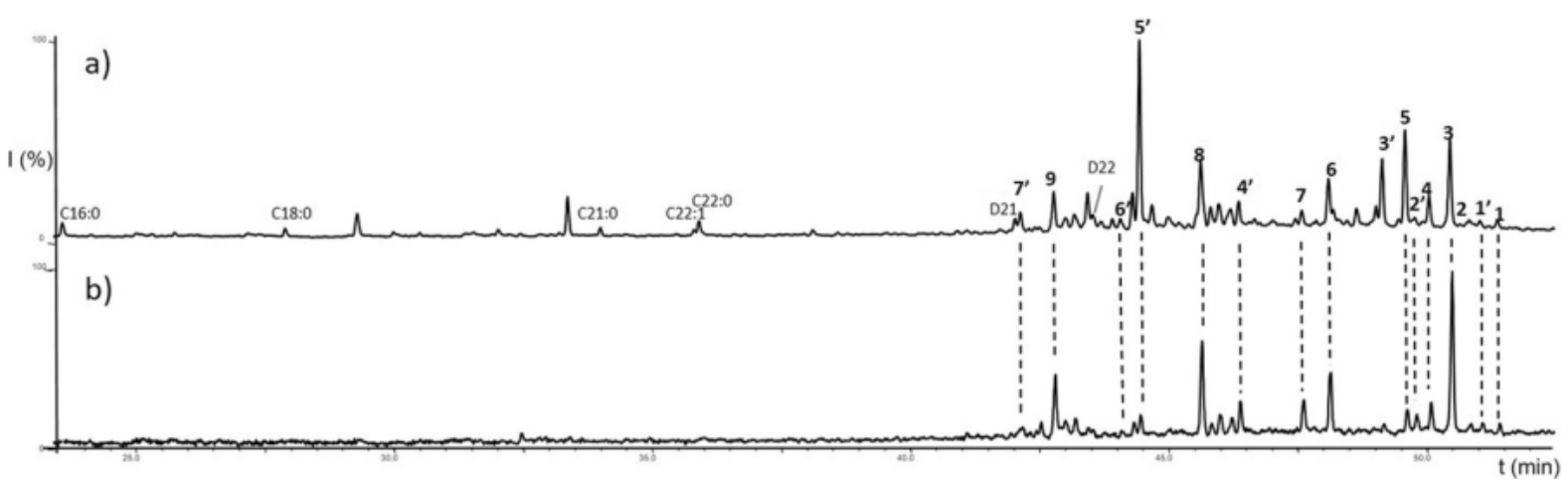

\footnotetext{
Figure 12 - Chromatograms of two samples from Structure 7 (Phase 2) of the site of Nice-Giribaldi: a tar from category 1a (MR6073), b tar from category 1b (MR6565). Biomarkers, slow heating markers and/or natural degradation markers are shown as peaks 1-9: 1, allobetuline; 2 , betulinic acid; 3, betulin; 4, betulone; 5, erythrodiol; 6, lupeol; 7, Lupenone; 8, lupa-2,20(29)-dien-28-ol; 9, lupa-2,20(29)-diene. Terpenes and strong heating markers (DPT + HPT) are shown as peaks 1' to 7': 1', 3-oxo-allobetulane; 2', 28-oxoallobetul-2ene; 3', $\alpha$ olean-28-al; 4', allobetul-2-ene; 5', b386 (hydrocarbon triterpene); 6', $\alpha$-allobetuline I; 7', b360 ( $\alpha$-hydro-carbon triterpene). Cx:y Fatty acids with x carbon atoms and y unsaturations, D diacids.
} 
Among the two less degraded classes, sub-categories could be distinguished based on their chemical signatures, including other molecular groups as fatty acids and strong heating markers (Figure 13).

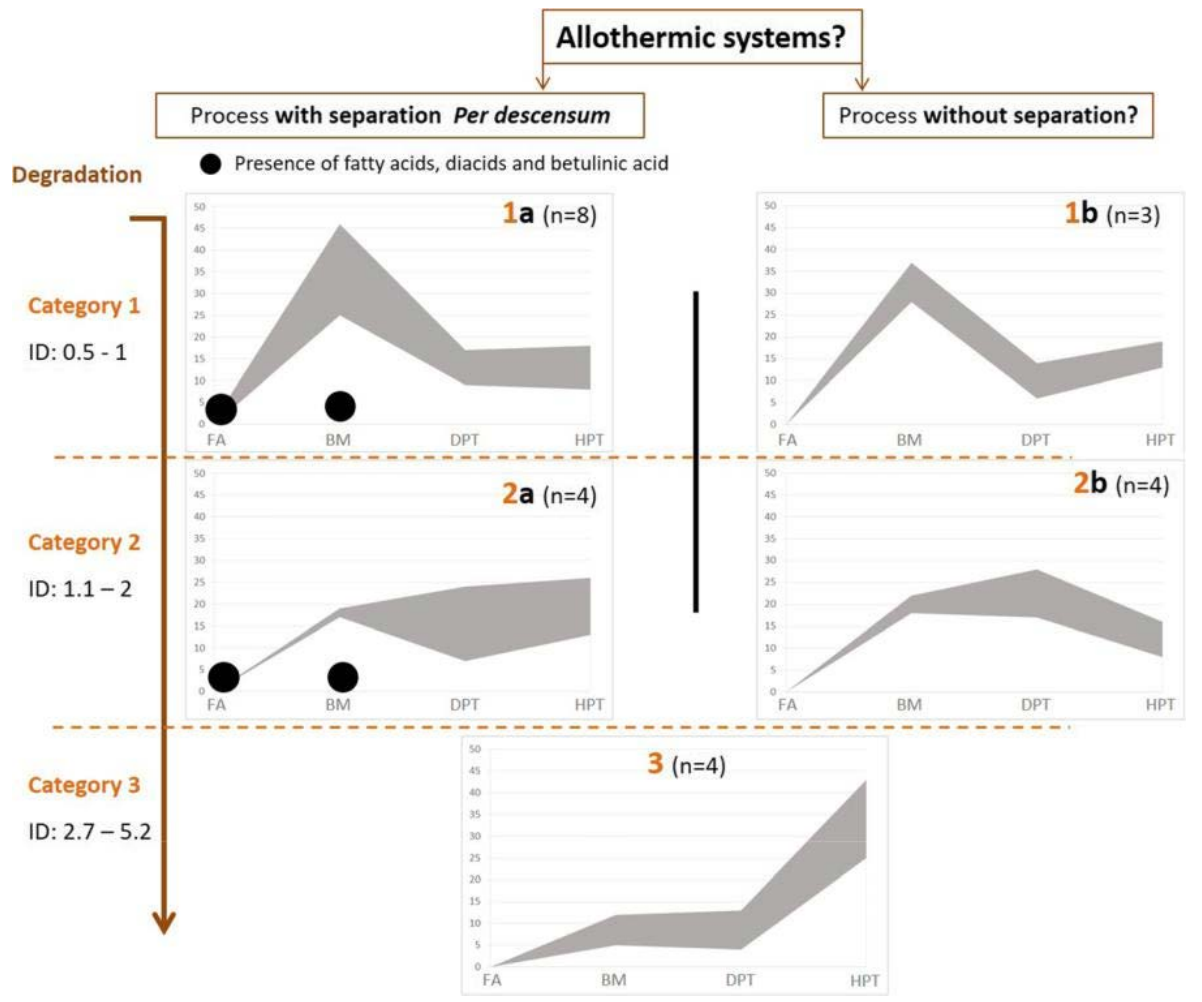

Figure 13 - Summary of chemical results obtained for samples from the site of Nice-Giribaldi. See section Different Manufacturing Processes, Heating Treatments, Life-Time and/or Reuse? for explanation of categories. 


\section{Different Manufacturing Processes, Heating Treatments, Life-Time and/or Reuse?}

Except for one case (MR6555), all samples have the same post-depositional history because they come from the similar burial conditions (pit filling) and were preserved in the same clay context. The differential degradation of biomarkers can thus be related to the anthropological history of the materials, e.g. manufacturing process, reheating and/or using. Degradation had less impact on the category 1 . To approach the system of production, we considered more specifically the samples less degraded from categories 1 and 2 (ID up to 2; $n=19$ ) in order to avoid complex history of the samples (high numbers of reheating, partial carbonisation, life-time and recycling) in the comparison of archaeological and experimental data:

1 - Category 1a $(\mathrm{n}=8)$ : presence of betulinic acid, fatty acids (in particular C22) and diacids suggests the use of a per descensum system to produce the tar. Markers of strong heating (DPT 9-17\%, HPT 8-19\%) could also suggest the use of a long heating system involving a process closer to the type "double-pot" than to the first exudations.

2 - Category $1 \mathrm{~b}(\mathrm{n}=3)$ : the absence of betulinic acid and fatty acids in well-preserved tars (according to the BM ratio and the ID) does not suggest the use of a per descensum system to manufacture the tar. Rather, the molecular signatures of these tars would correspond to a system without separation, as in the case of the single-pot production method using a soft heating treatment. Indeed, the DPT ratio is generally less important in this category than in our single-pot experiment (including with a slow temperature progression).

3 - Category 2a $(n=4)$ : The molecular signature is qualitatively similar to category $1 \mathrm{a}$. However, tars are more degraded, as shown by their ID, the ratio between biomarkers and the presence of markers of strong heating. Their fingerprint also suggests the use of a per descensum system to manufacture the tar closer to the type "double-pot" as observed for first exudations. The higher degradation of this category compared to category $1 \mathrm{~b}$ could be related to a more intense manufactur-ing process or non-oxidised reheating operations in the case of multiple uses.

4 - Category $2 \mathrm{~b}(\mathrm{n}=4)$ : The molecular signature is qualitatively similar to category $1 \mathrm{~b}$. However, the tars are more degraded, as shown by their ID, the ratio of biomarkers and, sometimes, by the presence of strong heating markers. The fingerprint also suggests the use of a system without separation to manufacture birch bark tar using a fast temperature increase or several reheating operations. Such a system could be considered chemically close to the type "single-pot" with a slow temperature progression.

The last two categories, $3(n=4)$ and $4(n=2)$, are characterised by a high extent of degradation, which does not allow us to discuss the original system of production. Strong heating treatments, a long period of use and/or multiple reuses could explain the degradation of these tars. However, it should be noted that the presence of betulinic acid, fatty acids (in particular C21 and C22) and diacids probably suggests the use of a per descensum system in three samples of category 3. 


\section{Discussion}

These experiments shed new light on the importance of controlling specific parameters for the optimal production of birch bark tar with ceramic vessel systems (bark quality, system of production, heating conditions). Furthermore, the combination of experimen-tal data and chemical investigation of both experimental and archaeological tars provides new lines of evidence on the systems of production of birch bark tar found at the neolithic site of Nice-Giribaldi.

\section{New Insights about Raw Material Management and Procurement}

Our experimental production of birch bark tar has shown that bark quality is of crucial importance to produce tar. Harvesting a supple and smooth bark was essential to obtain tar with the single-pot process. In the double-pot process, tar could also be produced using barks with warts. However, bark with internal warts seems to affect the yield. A good quality of bark from non-degraded dead birch tree or a middle-age birch with few warts was also easier and faster to harvest, allowing the production of a significant amount of tar in the most effective way. Such a strategy could even be consolidated by a seasonal production as bark can also be more easily detached from the trunk during sap flow period.

The resource management can be better appreciated as a result of our experimental approach. We obtain better knowledge of the quantity of bark needed to make tar. Our results lead us to estimate that about $2500 \mathrm{~g}$ of bark can be harvested from a birch with a very high potential (diameter of tree $0.6 \mathrm{~m}$, harvesting area $3 \mathrm{~m}$ high: about $1400 \mathrm{~g}$ of birch bark per $\mathrm{m}^{2}$ ). From $2500 \mathrm{~g}$ of bark, it should be possible to obtain around $750 \mathrm{~g}$ of liquid tar from the double-pot process and $1500 \mathrm{~g}$ of tar from the single-pot process according to our best yields in outdoor conditions (30 and 60\%, respectively). If the inner bark is not harvested, the tree will live; however bark regeneration may take one to three decades (Zasada 2000; M. Rageot, personal observations ${ }^{1}$ ethno-archaeology project ETAPAS). From this point of view, the existence of birch forests seems the only way to allow a regular and sustainable production of birch bark tar. In a geographic area where birch trees are scarce, birch bark and its sub-products have probably been imported and stored for regular use. Our experimental approach has shown that birch bark could be used up to at least 1 year after harvest to make tar, even though bark freshness could also impact yield. Further experiments need to be con-ducted to confirm that production directly following the harvest is more efficient, which could support a seasonal practice of tar production.

Even though this question has almost never been discussed in the archaeological literature dealing with birch bark tar, it is attested in ethno-archaeological, ethnographic and historical studies. A seasonal practice to harvest birch bark has been described, in particular, in North America (Osgood 1959) and in Siberia, as well as storage of the bark for many years before treatment in the Evenks populations (Henry et al. 2009).

Although these ethno-archaeological studies from North America and Siberia were conducted in a birch forest context, the resource management aspect is often described in terms of preservation as soon as possible (Osgood 1959; Henry et al. 2009). This should include a careful harvesting and a seasonality of acquisition to preserve the tree. For the Evenks in Siberia, the best period to collect birch bark is generally considered to be when the sap rises, in spring but sometimes later in the summer (Henry et al. 2009). Indeed, following the harvesting, birch trees need time to create a means of protection before winter. The new bark formed after 20 years is considered to be of better quality, and populations from North America revisit the same places after many years to harvest the bark (Osgood 1959). The careful selection of raw material is also reported in several ethnographical studies, even if it concerns wood tar. In Scandinavia, Morocco and Turkey, tar producers are attentive to the quality of wood and know the best places to find the resources. Their selection process targets the best part of the tree, which mostly

\footnotetext{
${ }^{1}$ Interviews with Evenk respondents from the Amur Region (Russian Federation) A. Makarov (Ust'Urkima) and with G. and A. Struchkov (Ivanovskoe) in Henry, A., Rageot, M., \& Kurovskaja, E. (2017). Rapport de mission ETAPAS: ethnoarchaeology of plant useby arctic and subarctic societies, projet IPEV: 1140, Mission 2017. Unpublished report.
} 
takes into account the physical aspect but also the odour of the wood (Egenberg et al. 2003; Hjulström et al. 2006; Kurt et al. 2008; Burri 2012).

Therefore, a real savoir-faire is necessary to produce birch bark tar, including, in particular, the choice of raw material and of the harvesting season. This also suggests anticipation of the needs and a yearscheduled procurement strategy.

Paleobotanic data indicate an unfavourable area for birch trees around the site of Nice-Giribaldi during the Middle Neolithic (Guillon 2014; Battentier et al. 2015): birch is rather rare in general in the Mediterranean area except in higher relief. However, birch bark tar was found in significant amount in Nice-Giribaldi (about $7 \mathrm{~g}$ in the pit rejections). Such data suggest mobility of raw material and existence of specific savoir-faire in local populations or, alternatively, the importation of the finished product. These hypotheses are compliant with the general context of meridional Chassean culture known for long-distance procurement networks. Indeed, during the Chassean period, exchanges increase between the Eastern Provence and other regions, especially for mineral materials such as obsidian flint, quartz, green stones or colouring materials (Binder 2004; Binder et al. 2008; Binder and Lepère 2014; Pradeau et al. 2016; Binder 2016). These spheres of acquisition include the Alps and the Vaucluse where birch forests were present.

\section{New Insights on Production Systems}

Our experimental tests have also contributed to a better understanding of the production methods. In the same way as for the raw material, systems of production of birch bark tar are rarely discussed for the prehistoric period, possibly because the connections between experimental studies and archaeological evidences are also rarely provided. Our experimental results showed that it is possible to distinguish tars made by different processes based on the presence of chemical markers (first exudations, double-pot and single-pot). A detailed characterisation by GC-MS of molecular markers such as triterpenes (biomarkers and markers of strong heating) and fatty acids can be consid-ered to be characteristic of the distinct heating treatments of the bark. These molecular markers are useful tools to discriminate different profiles which would suggest specific manufacturing systems, and then to help to reconstruct some of the missing steps of chaîne opératoire of birch bark tar. For the first time, we are able to highlight the processes of tar production during the Neolithic.

In this way, at least two methods of tar production were identified at Nice-Giribaldi. A per descensum system (categories 1a and 2a) was used to produce the tar found in the Proto-Chassey/SMP2 layers (Phase B). These tars contained markers of strong heating which appear after a long heating treatment, as observed for experimental birch bark tars produced by the double-pot method. Such a system was still in use during the early Chassey (Phase C) but is also associated in this period with tar produced by another method, probably different than the per descensum system (categories $1 \mathrm{~b}$ and $2 \mathrm{~b}$ ). This could suggest the acquisition of new savoir-faire and/or a diversification of procure-ment networks for birch bark tar at Nice-Giribaldi (Figure 14). The lack of data during the fifth millennium makes the discussion between tar needs and the spheres of activity difficult. Different hypothesis could be proposed, such as new hafting technology, increase in the number of ceramic treatments (reparation and/or sealing) or even new medicinal practices. Nevertheless, the choice, either cultural or technical, to use birch bark tar was made possible by the integration of the site of Nice-Giribaldi into acquisition networks that include birch forest areas. 
Different hypotheses can be proposed to explain the presence of at least two methods of production:

1 - A local production which combines craft and domestic manufacturing

2 - A local production combined with an import of the finished product

3 - Importation of tars from other places. The hypothesis of a regional importation from pre-Alps (from regional sphere) combined with a further importation from the Alps or Vaucluse could also be integrated into this hypothesis.

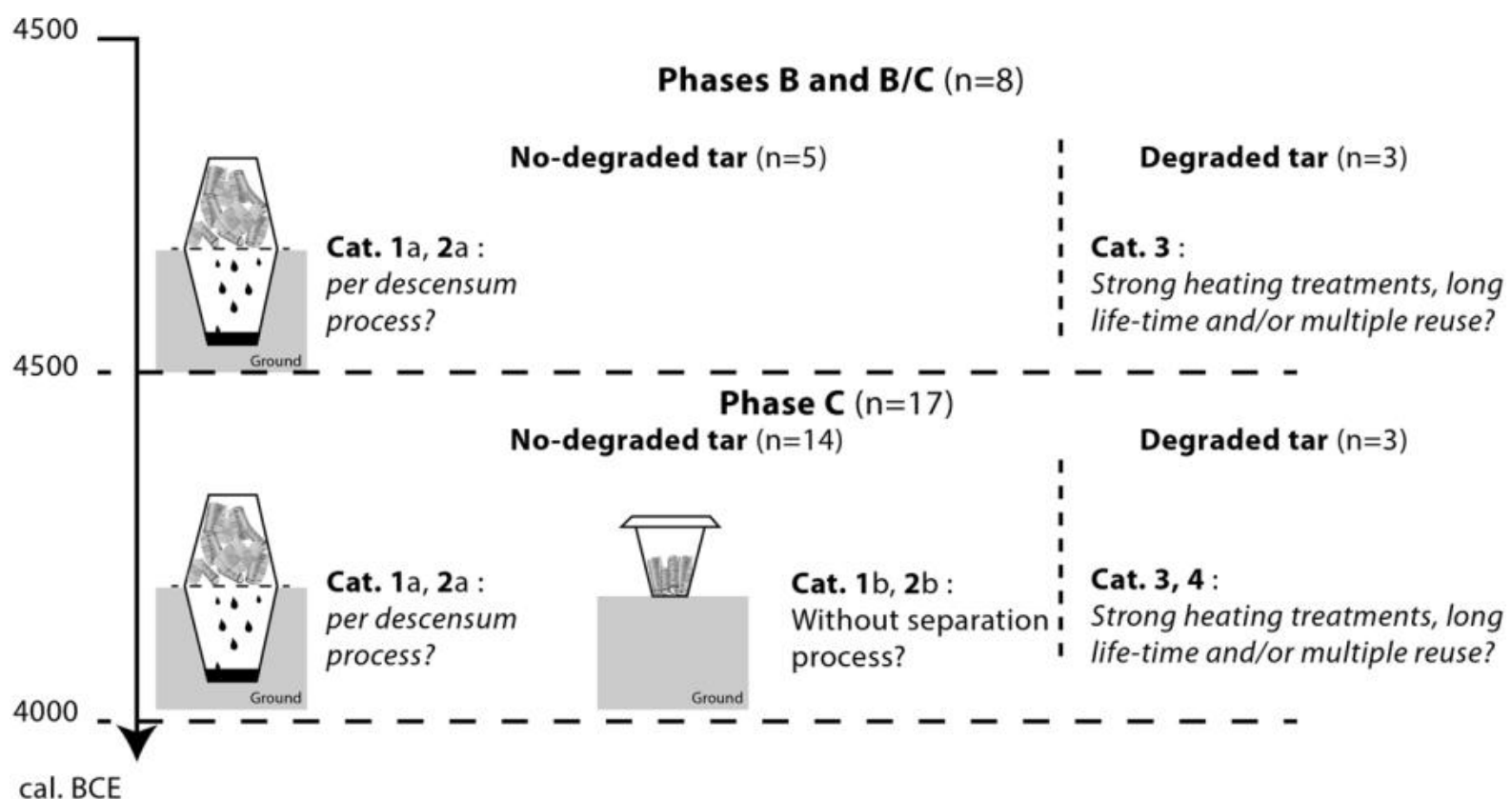

Figure 14 - Birch bark tar and its production systems in relation with the occupation phases at the site of NiceGiribaldi. Phase B = SMP2/Proto-Chassey, Phase B/C = Proto-Chassey/Early Chassey, Phase C = Early Chassey.

Future studies of birch bark tar and its systems of production from contemporary sites in areas favourable for birch tree growth will provide new data that may elucidate the network of acquisition of such material.

To date, the exact location of the production of birch bark tar has not been identified at prehistoric sites, but data are available for more recent periods, especially the Iron Age and Roman antiquity. In these cases, tar production is always located in remote areas of agglomerations among sources of raw material. Different hypotheses can be proposed to explain the lack of data at the site of Nice-Giribaldi and, more generally, for the Neolithic:

1 - Production located in close proximity with the raw material resource (in birch forests).

2 - Production of tar inside the village which then leaves very little archaeological evidence. These may be small, temporary structures which can be destroyed after being used, as described in ethnoarchaeological sources for North Africa (Gast 1999) or as the clay and stone structures described in experimental studies (Osipowicz 2005).

3 - Production at other sites, further way from the sources of raw material as well as the village (as some steps of lithic production). 
The specialisation of the activity (the sites or the people) needs also to be taken into consideration. Regarding the sites, production could be located in specialised work-shops dedicated to birch bark tar or at a non-specialised sites with other activities. Production could also be realised by specialists in a group (craft activity) or by non-specialists (domestic activity).

\section{Conclusion}

In our study, the combination of experimental and molecular approaches had provided new insights on birch bark management and tar production. It was indeed possible to highlight the importance of bark quality in the manufacture of tar, to show that the single-pot system needs a significant control of temperature and of bark quality compared to that based on the double-pot process and to establish relationships between molecular assemblages and manufacturing techniques. Our detailed molecular study of a series of 25 samples from the middle neolithic site of Nice-Giribaldi confirmed that birch bark tar is the single adhesive preserved at the site, distinguished different systems of production and added to our body of knowledge on the evolution of these production systems over time. These results are of great importance for our understanding of plant management and technical systems of prehistoric times.

Study has now to be extended to other manufacturing processes (aceramic or ceramic such as "pit methods" and "Peypin methods") and to focus on some specific parameters of the raw material (degradation and freshness of the bark) in order to investigate and integrate a larger variability of the practices.

Once more experience is gained in the production of tar (raw materials, heating treatment), the next objective will be to produce sufficient material for mechanical tests (see Gaillard et al. 2016) in order to better understand tar properties and how these are related to the manufacturing processes. Indeed, systems of production can influence the quality of the products obtained, which could be more appropriate in a technological point of view according to the adhesive function (hafting tools, mending and sealing vessels, etc.). The production of hafting adhesive for future experiments involving the shooting of projectile points is one example. Such a project has already been initiated with pine resin and beeswax (Gaillard et al. 2016). Last, degradation experiments in controlled burial conditions could be conducted to assess post-depositional alterations of birch bark tar; the additional study of the effect of re-heating and re-using birch bark tar could also be considered thoroughly.

\section{Acknowledgements}

The authors are very grateful to the ANR (Agence Nationale de la Recherche) and its financial support of the research programme EXSUDARCH dedicated to the chemistry, manufacture and use of plant exudates and tars. The results presented here are part of the $\mathrm{PhD}$ thesis of Maxime Rageot, funded by the CNRS, the Région PACA and the University of Nice Sophia Antipolis. We are grateful to these institutions for their support. The authors are also grateful to the French Polar Institute (IPEV) and its financial support of the research programme ETAPAS dedicated to the ethno-archaeology of plant use and exploitation (awarded to S. Beyries). We sincerely thank Jean-Denys Strich, Sabine Sorin and Pierre-Alain Gillioz for help in designing the figures. Lastly, we thank the reviewers for their fruitful comments. 


\section{References}

Aveling, E. M., \& Heron, C. (1998). Identification of birch bark tar at the Mesolithic site of star Carr. Ancient Biomolecules, 2, 69-80.

Aveling, E. M., \& Heron, C. (1999). Chewing tar in the early Holocene: An archaeological and ethnographic evaluation. Antiquity, 73(281), 579-584.

Balsan, L. (1951). L'industrie de la résine dans les Causses et son extension dans l'empire romain. Gallia, 9, 53-55.

Battentier, J., Thiébault, S., Binder, D., Théry-Parisot, I., Carré, A., \& Delhon, C. (2015). L’abri Pendimoun (Castellar, Alpes-Maritimes): évolution du couvert forestier et exploitation du milieu au Néolithique (5800-2000 cal. BCE). Quaternaire, 26, 279-292.

Binder, D. (2004). Giribaldi et la complexité des sociétés néolithiques. In D. Binder (Ed.), Un chantier archéologique à la loupe. Giribaldi (pp. 70-72). Nice Musées: Nice.

Binder, D. (2016). Approvisionnement et gestion des outillages lithiques au Néolithique: l'exemple de Giribaldi en Provence orientale. In A. Tomasso, D. Binder, G. Martino, G. Porraz, P. Simon, \& N. Naudinot (Eds.), Ressources lithiques, productions et transferts entre Alpes et Méditerranée. Actes de la séance de la Séance de la Société Préhistorique Française, Nice, 2013 (pp. 289-311): Société Préhistorique Française.

Binder, D., Bourgeois, G., Benoist, F., \& Vitry, C. (1990). Identification de brai de bouleau (betula) dans le néolithique de Giribaldi (Nice, France) par la spectrométrie de masse. Revue d'Archéométrie, 14, 37-42.

Binder, D., Lepère, C., \& Maggi, R. (2008). Epipaléolithique et Néolithique dans l'arc LiguroPorvençale. Bulletin du Musée d’Anthropologie préhistorique de Monaco, N 1, 49-62.

Binder, D., \& Lepère, C. (2014). From Impresso-Cardial to SMP and Chassey in Provence. Rivista di Studi Liguri, 77-79, 21-29.

Bonfield, K. M., Heron, C., Nemcek, N. (1997). The chemical Characterisation of wood tars in prehistoric Europe: A case study from Neolithic of southern Germany. In W. B. A. W. Piotrowski (Ed.), Proceeding of the first international symposium on wood tar and pitch (pp. 203-211). State Archaeological Museum: Warsaw.

Bosquet, D.,Regert,M., Dubois,N.,\& Jadin,I. (2001). Identificationde brai de bouleau sur quatre vases du site rubané de Fexhe-le-Haut-Clocher Podrî l'Cortri. Premiers résulrats. Notae Praehistoricae, 21, 119-127.

Bourquin-Mignot, C., Brochier, J.-E., Chabal, L., Crozat, S., Fabre, L., Guibal, F., et al. (1999). La botanique (Collection “Archéologiques”). Paris: Editions Errance.

Bruni, S., \& Guglielmi, V. (2014). Identification of archaeological triterpenic resins by the nonseparative techniques FTIR and 13C NMR: The case of Pistacia resin (mastic) in comparison with frankincense. Spectrochimica Acta Part A: Molecular and Biomolecular Spectroscopy, 121, 613622.

Burri, S. (2012). Vivre de l'inculte, vivre dans l'inculte en Basse Provence centrale à la fin du Moyen Âge. Histoire, archéologie et ethnoarchéologie d'un mode de vie itinérant. PhD thesis. Université Aix-Marseille.

Cassen, S., \& François, P. (2009). Les coupes-à-socles de la Table des Marchands et du néolithique ouest-européen. Projet de recomposition d'un objet archéologique total. In S. Cassen (Ed.), Autour de la Table. Explorations archéologiques et discours savants sur des architectures néolithique à Locmariaquer, Morbihan (Table des Marchands et Grand Menhir) (pp. 568-585). Vannes: Laboratoire de recherches archéologique, CNRS et Université de Nantes.

Charters, S., Evershed, R. P., Goad, L. J., Heron, C., \& Blinkhorn, P. (1993). Ifentification of on adhesive used to repair a roman jar. Archaeometry, 35(1), 91-101.

Colombini, M. P., \& Modugno, F. (2009). Organic mass spectrometry in art and archaeology. Chichester: Wiley. Colombini, M. P., Giachi, G., Iozzo, M., \& Ribechini, E. (2009). An Etruscan ointment from Chiusi (Tuscany, Italy): Its chemical characterization. Journal of Archaeological Science, 6(36), 1488-1495. 
Connan, J., Maurin, B., Long, L., \& Sebire, H. (2002). Identification de poix et de résine de Conifère dans des échantillons archéologiques du lac de Sanguinet : Exportation de poix en Atlantique à l'époque gallo-romaine. Revue d'Archéométrie, 26, 177-196.

Czarnowski, E., \& Neubauer, D. (1990). Aspekte zur Production und Verarbeitug von Birkenpech. Acta Praehistorica Archaeologica, 23, 11-13.

Czarnowski, E., Neubauer, D., \& Schwörer, P. (1990). Zur Herstellung von Birkenpech im Neolithikum. Acta Praehistorica et Archaeologica, 22, 169-173.

Daher, C., Paris, C., Le Hô, A.-S., Bellot-Gurlet, L., \& Echard, J.-P. (2010). A joint use of Raman and infrared spectroscopies for the identification of natural organicmedia used in ancient varnishes. Journal of Raman Spectroscopy, 41, 1494-1499.

Dal Ri, L., \& Tecchiati, U. (2003). Una distilleria per la pece della fine dell'età del bronzo dal lago di Ledro nel Trentino (loc. Longhini-Assat). In S. G (Ed.), Attraverso le Alpi (pp. 175-181). Stuttgart: Uomini, Vie, Beni, Konrad Theiss Verlag.

Ekman, R. (1983). The suberin monomers and triterpenoids from outer bark of Betula verrucosa Ehrh. Holforschung, 37, 205-211.

Egenberg, I. M., Aasen, J. A. B., Holtekjølen, A. K., \& Lundanes, E. (2002). Characterisation of traditionally kiln produced pine tar by gas chromatography-mass spectrometry. Journal of Analytical and Applied Pyrolysis, 62, 143-155.

Egenberg, I. M., Holtekjølen, A. K., \& Lundanes, E. (2003). Characterisation of naturally and artificially weathered pine tar coatings by visual assessment and gas chromatography-mass spectrometry. Journal of Cultural Heritage, 4, 221-241.

Evans, K., \& Heron, C. (1993). Glue, disinfectant and chewing gum: Natural products chemistry in archaeology. Chemistry and Industry, 21, 446-449.

Evershed, R. P., Jerman, K., \& Eglinton, G. (1985). Pine wood origin for pitch from the Mary rose. Nature, 314, 528-530.

Gaillard, Y., Chesnaux, L., Girard, M., Burr, A., Darque-Ceretti, E., Felder, E., et al. (2016). Assessing hafting adhesive efficiency in the experimental shooting of projectile points: A new device for instrumented and ballistic experiments. Archaeometry, 58, 465-483.

Garnier, N. (1999). Détermination de la structure moléculaire d'écorces actuelles et d'adhésifs archéologiques par chromatographie en phase gazeuse couplée à la spectrométrie de masse (CPGSM). Master thesis. Univesité Paris VI, Paris.

Gast, M. (1999). G63. Goudron. In G. Camps (Ed.), Encyclopédie berbère (pp. 3170-3174). Aix-enProvence: Edisud.

Grünberg, J. M. (2002). Middle Palaeolithic birch-bark pitch. Antiquity, 76, 15-16.

Guillon, S. (2014). Dynamique de la végétation alluviale côtière dans le Sud-Est de la France (bassins versants du Loup et de la Cagne, Alpes-Maritimes) au cours de la première moitié de l'Holocène. PhD thesis. Nice: Université Nice Sophia-Antipolis.

Groom, P., Schenck, T., \& Pedersen, G. M. (2015). Experimental explorations into the aceramic dry distillation of Betula pubescens (downy birch) bark tar. Archaeological and Anthropological Sciences, 7, 47-58.

Hastorf, C. A., \& Popper, V. S. (1989). Current paleoethnobotany: Analytical methods and cultural interpre-tations of archaeological plant remains (prehistoric archaeology and ecology series). Chicago: University of Chicago Press.

Hayek, E. W. H., Krenmayr, P., Lohninger, H., Jordi, U., Moche, W., \& Sauter, F. (1990). Identification of archaeological and recent wood tar pitches using gas chromatography/mass spectrometry and pattern recognition. Analytical Chemistry, 62, 2038-2043.

Henry, A., \& Théry-Parisot, I. (2014). From Evenk campfires to prehistoric hearths: Charcoal analysis as a tool for identifying the use of rotten wood as fuel. Journal of Archaeological Science, 52, 321-336.

Henry, A., Théry-Parisot, I., \& Voronkova, E. (2009). La gestion du bois de feu en Forêt Boréale : problématique archéo-anthracologique et étude d'un cas ethnographique (Région De l'Amour, Sibérie). In I. Théry-Parisot, S. Costamagno, \& A. Henry (Eds.), Gestion des combustibles au paléolithique et au mésolithique Nouveaux outils, nouvelles interprétations Fuel Management 
during the Palaeolithic and Mesolithic Periods New tools, new interpretations (pp. 17-37): BAR 1914. Oxford: Archaeopress.

Hjulström, B., Isaksson, S., \& Hennius, A. (2006). Organic geochemical evidence for pine tar production in middle eastern Sweden during the roman iron age. Journal of Archaeological Science, 33, 283294.

Jauch, V. (1994). Eine römanische Teersiederei im antiken Tasgetium-Eschenz. Archéologie suisse, 17(3), 11-119. Julin, M. (2008). Tar production - traditional medicine and potential threat to biodiversity in the Marrakesh region An ethnobotanical study. Degree project in biology. Sweden: Uppsala University.

Koller, J., \& Baumer, U. (2001). High-tech in the middle Palaeolithic: Neandertal-manufactured pitch identified. European Journal of Archaeology, 4(3), 385-397.

Kozowyk, P. R. B., Soressi, M., Pomstra, D., \& Langejans, G. H. J. (2017). Experimental methods for the Palaeolithic dry distillation of birch bark: Implications for the origin and development of Neandertal adhesive technology. Scientific Reports, 7, 8033.

Krasutsky, P. A. (2006). Birch bark research and development. Natural Product Reports, 23(6), 919942. Kurt, Y., Suleyman Kaçar, M., \& Isik, K. (2008). Traditional tar production from Cedrus libani A. Rich on the

Taurus Mountains in southern Turkey. Economic Botany, 62(4), 615-620.

Kurt, Y., \& Isik, K. (2012). Comparison of tar produced by traditional and laboratory methods. Studies on Ethno-Medicine, 6(2), 77-83.

Kurzweil, A., \& Todtenhaupt, D. (1991). Technologie der Holzteergewinnung. Acta Praehistorica et Archaeologica, 23, 63-91.

Lavoie, S. (2001). Contribution à la synthèse de dérivés de l'acide bétulnique à partir du betulinol extrait de l'ecorce du bouleau blanc (betula papyrifera). Master thesis, Université du Québec à Chicoutimi. http://constellation.uqac.ca/914/1/12332457.pdf.

Lepers, C. (1997). Brai, résine, goudron et autres. Bulletin des chercheurs de la Wallonie, 37,113-132.

Li, T.-S., Wang, J.-X., \& Zheng, X.-J. (1998). Simple synthesis of allobetulin, 28-oxyallobetulin and related biomarkers from betulin and betulinic acid catalysed by solid acids. Journal of Chemical Society Perkin Transactions, 1(23), 3957-3966.

Lucquin, A., March, R. J., \& Cassen, S. (2007). Analysis of adhering organic residues of two "coupleà-socles" from the neolithic funerary site "la Hougue Bie" in Jersey: Evidences of birch bark tar utilisation. Journal of Archaeological Science, 34, 704-710.

Mazza, P. P. A., Martini, F., Sala, B., Magi, M., Colombini, M. P., Giachi, G., et al. (2006). A new Palaeolithic discovery: Tar-hafted stone tools in a European mid-Pleistocene bone-bearing bed. Journal of Archaeological Science, 33, 1310-1318.

Mirabaud, S., Pétrequin, A.-M., Pétrequin, P., \& Regert, M. (2015). Système de production des adhésifs exploités à Clairvaux VII et Clairvaux XIV. In P. Pétrequin, \& A.-M. Pétrequin (Eds.), Clairvaux et le "Néolithique Moyen Bourguignon" (Vol. Tome 2, pp. 1001-1021). Centre de Recherche Archéologique de la Vallée de l’Ain: Presses universitaires de Franche-Comté.

Mitkidou, S., Dimitrakoudi, E., Urem-Kotsou, D., Papadopoulou, D., Kotsakis, K., Stratis, J. A., et al. (2008). Organic residue analysis of Neolithic pottery from North Greece. Microchimica Acta, 160, 493-498.

Neubauer-Saurer, D. (1997). Birkenpechproduktion im Neolithikum (ein mögliches verfahren). In W. B. A. W. Piotrowski (Ed.), Poceeding of the first international symposium on wood tar and pitch (pp. 41-44). State Archaeological Museum: Warsaw.

Orengo, H. A., Palet, J., Ejarque, A., Miras, Y., \& Riera, S. (2013). Pitch production during the roman period: An intensive mountain industry for a globalised economy? Antiquity, 87, 802-814.

Osgood, C. (1959). Ingalik mental culture (Vol. 56): Yale university publications in anthropology. New Haven: Yale University.

Osipowicz, G. (2005). A method of wood tar production, without the use of ceramics. In (RE)constrution and experiment in archaeology. European Platform, 2, 11-17.

Palmer, F. (2007). Die Entstehung von Birkenpech in einer Feuerstelle unter paläolithischen Bedingungen. Mitteilungen der Gesellschaft für Urgeschichte, 16, 75-83. 
Pawlik, A. (2011). Die funktionale Analyse der Steingeräte und die Rekonstruktion der Aktivitäten am Ullafelsen. In D. Schäfer (Ed.), Mensch und Umwelt im Holozän Tirols (Vol. 1, pp. 319-424). Innsbruck: Philipp von Zabern.

Pradeau, J.-V., Binder, D., Verati, C., Lardeaux, J.-M., Dubernet, S., Lefrais, Y., et al. (2016). Procurement strategies of Neolithic colouring materials: Territoriality and networks from 6th to 5th millennia BCE in north-western Mediterranean. Journal of Archaeological Science, 71, 10 23.

Rameau, J. C., Manson, D., \& Dumé, G. (1993). Flore forestière française Tome 2, Montagnes. DijonQuetigny: Institut Pour Le Developpement Forestier.

Rameau, J. C., Manson, D., \& Dumé, G. (2008). Flore forestière française Tome 3, Région Méditerranéenne. Dijon-Quetigny: Institut Pour Le Developpement Forestier.

Rageot, M. (2015). Les substances naturelles en Méditerranée nord-occidentale (VIe-Ie Millénaire BCE) : chimie et archéologie des matériaux exploités pour leurs propriétés adhésives et hydrophobes. Unpublished PhD thesis. Nice: Université Nice Sophia Antipolis.

Rageot, M., Pêche-Quilichini, K., Py, V., Filippi, J. J., Fernandez, X., \& Regert, M. (2016). Exploitation of beehive products, plant exudates and tars in Corsica during the early iron age. Archaeometry, 58, 315-332.

Rajewski, Z. (1970). Pech und Teer bei den Slaven. Zeitschrift für Achäologie, 4, 46-53.

Regert, M. (1996). Les composés organiques en préhistoire : nouvelles approches analytiques. Unpublished $\mathrm{PhD}$ thesis. Nanterr: Université Paris X.

Regert, M., Delacotte, J.-M., Menu, M., Pétrequin, P., \& Rolando, C. (1998). Identification of neolithic hafting adhesives from two lake dwellings at Chalain (Jura, France). Ancient Biomolecules, 2, 81-96.

Regert, M., Garnier, N., Binder, D., \& Pétrequin, P. (2000). Les adhésifs néolithiques : quels matériaux utilisés, quelles techniques de production dans quel context social? L'exemple des adhésifs des sites de Giribaldi et de Chalain. In Arts du feu et productions artisanales. XXe rencontres internationales d'archéologie et d'histoire Antibes (pp. 585-604). Antibes: Editions APDCA.

Regert, M., \& Rolando, C. (2002). Identification of archaeological adhesives using direct inlet electron ionization mass spectrometry. Analytical Chemistry, 74(5), 965-975.

Regert, M., Vacher, S., Moulherat, C., \& Decavallas, O. (2003). Ahesive production and pottery function during the iron age at the site of grand Aunay (Sarthe, France). Archaeometry, 45(1), 101-120.

Regert, M., Alexandre, V., Thomas, N., \& Lattuati-Derieux, A. (2006). Molecular characterisation of birch bark tar by headspace solid-phase microextraction gas chromatography-mass spectrometry: A new way for identifying archaeological glues. Journal of Chromatography A, 1101, 245-253.

Regert, M., Devièse, T., Le Hô, A.-S., \& Rougeulle, A. (2008). Reconstructing ancient Yemeni commercial routes during the middle ages using structural characterization of terpenoid resins. Archaeometry, 50(4), 668-695.

Regert, M., \& Mirabaud, S. (2014). Substances naturelles exploitées sur les sites de Chalain et Clairvaux : nature et fonction des matériaux organiques amorphes. In R.-M. Arbogast, \& A. Greffier-Richard (Eds.), Entre archéologie et écologie, une Préhistoire de tous les milieux. Mélanges offerts à Pierre Pétrequin (pp. 79-91). Besançon: Presses universitaires de FrancheComté.

Reunanen, M., Ekman, R., \& Hafizoglu, H. (1996). Composition of tars from softwoods and birch. Holzforschung, 50(2), 118-120.

Ribechini, E., Bacchiocchi, M., Deviese, T., \& Colombini, M. P. (2011). Analytical pyrolysis with in situ thermally assisted derivatisation, Py(HMDS)-GC/MS, for the chemical characterization of archaeological birch bark tar. Journal of Analytical and Applied Pyrolysis, 91, 219-223.

Sauter, F., Ulrich, J., Graf, A., Werther, W., \& Varmuza, K. (2000). Studies in organic archaeometry I: Identification of the prehistoric adhesive used by "Tyrolean icemen" to fix his weapons. Arkivoc, 5, 735-747. Sauter, F., Varmuza, K., Werther, W., \& Stadler, P. (2002). Studies in organic archaeometry V: Chemical analysis of organic material found in traces on an Neolithic terracotta idol statuette excavated in lower Austria. Arkivoc, 1, 54-60. 
Schenck, T., \& Groom, P. (2018). The aceramic production of Betula pubescens (downy birch) bark tar using simple raised structures. A viable Neanderthal technique? Archaeological and Anthropological Sciences, 10(1), 19-29.

Schoknecht, U., \& Schwartze, E. (1964). Hinweise zur Pechbereitung in fruhslawischer Zeit. Ausgrabung und Funde, 12, 205-210.

Stern, B., Heron, C., Tellefsen, T., \& Serpico, M. (2008). New investigations into Uluburun resin cargo. Journal of Archaeological Science, 35, 2188-2203.

Szafranski, W. (1997). Die frühmittelalterlische teerschwele in Biskupin. In W. B. A. W. Piotrowski (Ed.), Poceeding of the first international symposium on wood tar and pitch. Warsaw: State archaeological museum.

Théry-Parisot, I., Thiebault, S., Delannoy, J. J., Ferrier, C., Feruglio, V., Fritz, C., et al. (accepted). Lluminating the cave, drawing with black wood charcoal: New insights from la Grotte Chauvet (Vallon-Pont d'Arc, France) through charcoal fragments analysis. Antiquity.

Thiébault, S. (2010). Archéologie environnementale de la France. Paris: La Découverte.

Trintignac, A. (2003). La production de poix dans la cité des gabales (Lozère) à l'époque gallo-romaine. RAP. 1/2, 239-248.

Ukkonen, F. K., \& Erä, V. (1979). Birch bark extractives. Kemia-Kemi, 5, 217-220.

Urem-Kotsou, D., Stern, B., Heron, C., \& Kotsakis, K. (2002). Birch bark tar at Neolithic Makriyalos, Greece. Antiquity, 76, 962-967.

Voß, R. (1997). Slawische keramik zur teergewinnung vom 7.-12. Jh. in Mecklenburg und Vorpommern. In W. B. A. W. Piotrowski (Ed.), Proceedings of the first international symposium on wood tar and pitch (pp. 81-86). State Archaeological Museum: Warsaw.

Zakoscielna, A., \& Gurba, J. (1997). Frühmittelalterliche holzteergruben in Lopiennik Dolny in der Woiwodschaft Chelm. In W. B. A. W. Piotrowski (Ed.), Proceedings of the first international symposium on wood tar and pitch (pp. 73-79). State Archaeological Museum: Warsaw.

Zasada, J. (2000). Birch saps arisin'! So what you ask?-Some considerations about non-timber forest products from paper birch. In H. Chen, A. Luke, \& W. Bidwell (Eds.), Proceedings for the ecology and management of white birch workshop, Wawa, Ontario, 2000 (pp. 3): Ontario. 